Article

\title{
Genome-Wide Homozygosity Patterns and Evidence for Selection in a Set of European and Near Eastern Horse Breeds
}

\author{
Gertrud Grilz-Seger ${ }^{1, *}$, Markus Neuditschko ${ }^{2}$, Anne Ricard ${ }^{3}$, Brandon Velie ${ }^{4,5}$, \\ Gabriella Lindgren ${ }^{4,6}{ }^{\mathbb{1}}$, Matjaz Mesarič ${ }^{7}$, Marko Cotman ${ }^{8}$, Michaela Horna ${ }^{9}$, \\ Max Dobretsberger ${ }^{1}$, Gottfried Brem ${ }^{1}$ and Thomas Druml ${ }^{1}$ \\ 1 Institute of Animal Breeding and Genetics, University of Veterinary Sciences Vienna, Veterinärplatz 1, \\ 1210 Vienna, Austria \\ 2 Agroscope, Swiss National Stud Farm, Les Longs Prés, CH-1580 Avenches, Switzerland \\ 3 UMR 1313 Génétique Animale et Biologie Intégrative, Institut National de la Recherche Agronomique, \\ Domaine de Vilvert, Bat 211, 78352 Jouy-en-Josas, France \\ 4 Department of Animal Breeding \& Genetics, Swedish University of Agricultural Sciences, Ulls väg 26, \\ 75007 Uppsala, Sweden \\ 5 School of Life and Environmental Sciences, University of Sydney, Eastern Ave, Sydney, NSW 2006, Australia \\ 6 Livestock Genetics, Department of Biosystems, KU Leuven, 3001 Leuven, Belgium \\ 7 Clinic for Reproduction and Large Animals, University of Ljubljana, Veterinary, Faculty, \\ Cesta v Mestni log 47, 1000 Ljubljana, Slovenia \\ 8 Institute for Preclinical Sciences, University of Ljubljana, Veterinary Faculty, Gerbičeva 60, \\ 1000 Ljubljana, Slovenia \\ 9 Department of Animal Husbandry, Slovak University of Agriculture in Nitra, Tr. A. Hlinku 2, \\ 94976 Nitra, Slovakia \\ * Correspondence: gertrud.grilz@vetmeduni.ac.at
}

Received: 14 May 2019; Accepted: 26 June 2019; Published: 28 June 2019

check for updates

\begin{abstract}
Intensive artificial and natural selection have shaped substantial variation among European horse breeds. Whereas most equine selection signature studies employ divergent genetic population structures in order to derive specific inter-breed targets of selection, we screened a total of 1476 horses originating from 12 breeds for the loss of genetic diversity by runs of homozygosity $(\mathrm{ROH})$ utilizing a 670,000 single nucleotide polymorphism (SNP) genotyping array. Overlapping homozygous regions ( $\mathrm{ROH}$ islands) indicating signatures of selection were identified by breed and similarities/dissimilarities between populations were evaluated. In the entire dataset, $180 \mathrm{ROH}$ islands were identified, whilst 100 islands were breed specific, all other overlapped in 36 genomic regions with at least one $\mathrm{ROH}$ island of another breed. Furthermore, two ROH hot spots were determined at horse chromosome 3 (ECA3) and ECA11. Besides the confirmation of previously documented target genes involved in selection for coat color $(M C 1 R, S T X 17, A S I P)$, body size (LCORL/NCAPG, ZFAT, LASP1, HMGA2), racing ability (PPARGC1A), behavioral traits (GRIN2B, NTM/OPCML) and gait patterns (DMRT3), several putative target genes related to embryonic morphogenesis (HOXB), energy metabolism (IGFBP-1, IGFBP-3), hair follicle morphogenesis (KRT25, KRT27, INTU) and autophagy (RALB) were highlighted. Furthermore, genes were pinpointed which might be involved in environmental adaptation of specific habitats (UVSSA, STXBP4, COX11, HLF, MMD).
\end{abstract}

Keywords: $\mathrm{ROH}$ island; selection signature; body size; coat color; autophagy; altitude adaptation; embryonic morphogenesis 


\section{Introduction}

The scientific interest in the identification of selection signatures in horses successively rose with the enhancement of whole-genome sequencing and analysis methods. A milestone in equine genetics is the population study of $\mathrm{Gu}$ et al. [1] that concentrated on the identification of selection targets in thoroughbreds using microsatellite markers. With the availability of cost extensive high throughput single nucleotide polymorphism (SNP) data, several studies were conducted to scan the genome of numerous horse populations for genetic diversity [2,3], and for selection signatures [4-7]. Furthermore, the capability of archaeogenomics to isolate and analyze ancient DNA enabled the comparison of the ancient equine genome with modern breeds, which highlighted the genomic changes during the domestication process [8,9]. Most of these studies employ methods which ascertain the loss of diversity in order to capture breed divergent patterns of molecular variation, among them $\mathrm{F}_{\mathrm{ST}}$ statistics being the most popular [10,11]. In other livestock species, authors investigated selection signatures based on common shared runs of homozygosity ( $\mathrm{ROH}$ islands) [12-15]. To date, several studies applying this approach on horses were published [16-21]. To our knowledge, one of the first equine studies scanning the genome for runs of homozygosity $(\mathrm{ROH})$ in order to detect selection signatures was performed by Metzger et al. [16] using the next generation sequencing data of 10 horses (three horses originating from primitive breeds and seven horses originating from modern breeds). Grilz-Seger et al. $[17,18]$ and Velie et al. [19] investigated ROH island patterns within single breeds using genotype information of the 670k SNP genotyping array. A comparison of overlapping homozygous regions between three different breeds with a small population size using 670k SNP data was performed by Grilz-Seger et al. [20], whilst Nolte et al. [21] investigated four German sport horse breeds based upon 50k SNP data. In this study, we investigated a highly diverse breed panel of 12 European and Near-Eastern horse breeds, comprising in total 1476 horses, for potential signatures of selection utilizing the 670kSNP genotyping array (Table 1). The horses were selected to represent a North-South gradient ranging from Great Britain over Central and South-Eastern Europe to the Near East (Figure 1).

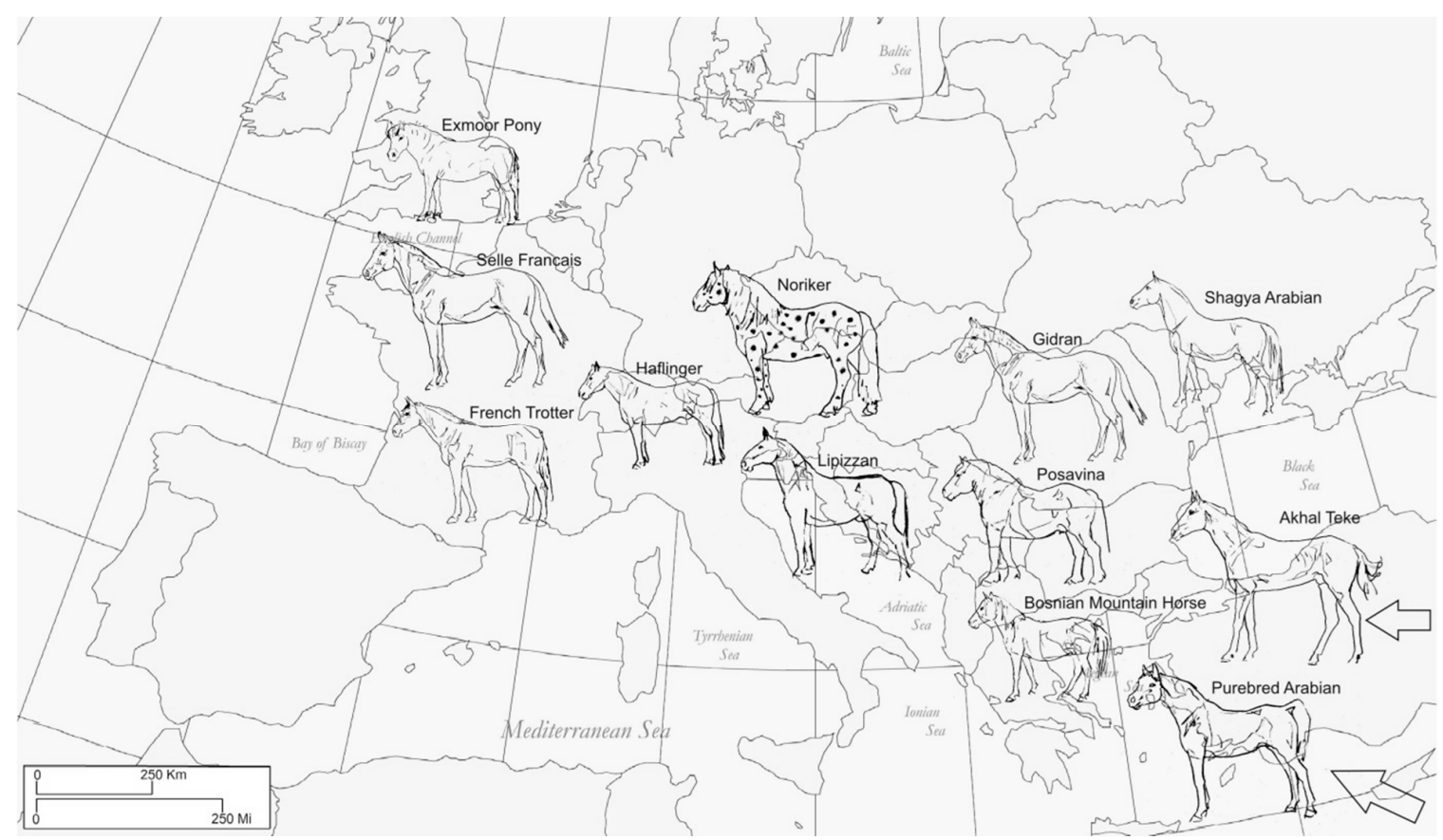

Figure 1. Geographic origin of twelve investigated European and Near Eastern horse breeds (Graphics Thomas Druml). 
Table 1. Characterization of breeds, population history, sample location and number of sampled horses $(\mathrm{N})$.

\begin{tabular}{|c|c|c|c|}
\hline Breed/Classification & Gene Pool & $\begin{array}{c}\text { Region of } \\
\text { Origin/Sample Origin }\end{array}$ & Population Notes and Census \\
\hline $\begin{array}{l}\text { Exmoor Pony } \\
\text { small sized, multipurpose } \\
\text { working horse }\end{array}$ & Native English breed & British Isles/UK & $\begin{array}{l}\text { Closed stud book since 1921, ca. } \\
2.000 \text { animals [2] }\end{array}$ \\
\hline $\begin{array}{l}\text { Selle Francais } \\
\text { Riding horse }\end{array}$ & $\begin{array}{c}\text { French Trotter, } \\
\text { Thoroughbred, Arabian }\end{array}$ & France/FRA & $\begin{array}{l}\text { Stud book founded 1958; ca. } 12.700 \\
\text { breeding animals [22] }\end{array}$ \\
\hline $\begin{array}{c}\text { French Trotter } \\
\text { harness racing (trot) }\end{array}$ & $\begin{array}{l}\text { Anglo Norman, } \\
\text { Standardbred }\end{array}$ & France/FRA & $\begin{array}{l}\text { Stud book closed since } 1937, \text { allows } \\
\text { Standardbred; } 15.500 \text { breeding } \\
\text { animals [23] }\end{array}$ \\
\hline $\begin{array}{l}\text { Lipizzan } \\
\text { riding, driving }\end{array}$ & $\begin{array}{l}\text { Old-Spanish and } \\
\text { Oriental breeds }\end{array}$ & $\begin{array}{c}\text { Austro-Hungarian/Lipizzan } \\
\text { Stud farms AT, SLK, } \\
\text { HUN, HR }\end{array}$ & $\begin{array}{l}\text { Founded } 1580 \text {, closed studbook since } \\
1880 \text {; ca. } 2.000 \text { breeding animals in } \\
\text { European state stud farms [24] }\end{array}$ \\
\hline $\begin{array}{c}\text { Noriker } \\
\text { heavy working draught horse }\end{array}$ & Native Austrian breed & Austria/AT & $\begin{array}{l}\text { Very old breed, closed stud book since } \\
1880 ; \text { ca. } 4.000 \text { breeding animals [25] }\end{array}$ \\
\hline $\begin{array}{l}\text { Haflinger } \\
\text { light draught horse, } \\
\text { multipurpose }\end{array}$ & $\begin{array}{l}\text { Derived from local and } \\
\text { Galizian mares, and } \\
\text { influenced by Arabian, } \\
\text { Gidran, Noriker }\end{array}$ & Austria/AT & $\begin{array}{c}\text { Founded 1898, closed studbook since } \\
\text { 1928; ca. } 6.000 \text { breeding animals in } \\
\text { Austria [26] }\end{array}$ \\
\hline $\begin{array}{l}\text { Posavina } \\
\text { small draught horse, heavy } \\
\text { working }\end{array}$ & $\begin{array}{l}\text { Native Croatian breed, } \\
\text { influenced by Ardenner, } \\
\text { Bosnian Mountain Horse }\end{array}$ & Croatia/SLO & $\begin{array}{c}\text { Closed studbook since 1994; ca. } 600 \\
\text { breeding animals in Slovenia [27] }\end{array}$ \\
\hline $\begin{array}{l}\text { Gidran } \\
\text { multipurpose riding horse }\end{array}$ & $\begin{array}{l}\text { Arabian, English } \\
\text { Thoroughbred, } \\
\text { Old-Spanish }\end{array}$ & $\begin{array}{l}\text { Stud farms Mezöhegyes, } \\
\text { Radautz (Austro - } \\
\text { Hungarian empire)/HUN }\end{array}$ & $\begin{array}{c}\text { Closed studbook since 1860, } \\
\text { introgression of some Arabian and } \\
\text { Thoroughbred horses; ca. 250 } \\
\text { breeding animals in Hungary [28] }\end{array}$ \\
\hline $\begin{array}{l}\text { Shagya Arabian } \\
\text { endurance and multipurpose } \\
\text { riding horse }\end{array}$ & $\begin{array}{l}\text { Original Arabians from } \\
\text { Syria, influence by } \\
\text { Russian founder mares }\end{array}$ & $\begin{array}{l}\text { Stud farms Babolna, } \\
\text { Mezöhegyes, Radautz } \\
\text { (Austro - Hungarian } \\
\text { empire)/SLK }\end{array}$ & $\begin{array}{c}\text { Closed studbook since 1830, Purebred } \\
\text { Arabians allowed; ca. } 2.000 \text { breeding } \\
\text { animals [29] }\end{array}$ \\
\hline $\begin{array}{l}\text { Bosnian Mountain Horse } \\
\text { small multipurpose } \\
\text { working horse }\end{array}$ & $\begin{array}{l}\text { Native breed of the } \\
\text { Balkan Peninsula, } \\
\text { influenced by Arabian }\end{array}$ & $\begin{array}{c}\text { Bosnia and } \\
\text { Herzegovina/BIH, SLO }\end{array}$ & $\begin{array}{l}\text { Purebred, very old breed; } 114 \\
\text { registered animals in the International } \\
\text { Association of Bosnian Mountain } \\
\text { Horse Breeders [30] }\end{array}$ \\
\hline $\begin{array}{l}\text { Purebred Arabian } \\
\text { endurance and multipurpose } \\
\text { riding horse }\end{array}$ & Original Arabian & Egypt, Near East/FRA & Purebred, very old breed; worldwide \\
\hline $\begin{array}{c}\text { Akhal Teke } \\
\text { Endurance horse }\end{array}$ & Native Middle East & Turkmenistan/RUS & $\begin{array}{l}\text { Purebred, stud book closed 1941; ca. } \\
\quad 3.500 \text { breeding animals [2] }\end{array}$ \\
\hline
\end{tabular}

The main objective of this study was to determine levels of autozygosity, with a special focus on overlapping homozygous regions ( $\mathrm{ROH}$ islands) within and between breeds, in order to identify breed-specific signatures of selection. Furthermore, we conducted a gene ontology (GO) and enrichment analysis and compared and discussed resulting gene ontologies within our breed panel.

\section{Materials and Methods}

\subsection{Sampling}

The sample comprised 1476 horses from ten European and two Near Eastern horse breeds, whereas the single breeds belonged to different phenotype categories: two heavy draught horse breeds (Noriker, $\mathrm{n}=174$, Posavina, $\mathrm{n}=28$ ), two small sized autochthonous breeds (Exmoor Pony, $\mathrm{n}=104$, Bosnian Mountain Horse, $n=23$ ), two Arabian breeds (Purebred Arabian, $n=155$, Shagya Arabian, $n=32$ ), three Warmblooded breeds (Selle Francais, $n=294$, Lipizzan, $n=377$, Gidran, $n=20$ ), one racing breed (French Trotter, $\mathrm{n}=156$ ), one small to medium sized multipurpose working breed (Haflinger, $\mathrm{n}=78)$ and the Akhal Teke ( $\mathrm{n}=35)$ (Table 1). Three of the sampled breeds can be considered as very old (Noriker, Bosnian Mountain Horse and Exmoor Pony) and are kept under semi-feral conditions on a long term. 
The majority of the horses (Haflinger, Noriker, Lipizzan, Posavina, Bosnian Mountain Horse, Gidran and Shagya Arabian) were selected in order to represent the genealogical population structure (sire lines and mare families) of the respective breeds based on pedigree information. For Akhal Teke, French Trotter and Selle Francais, the horses were chosen to be unrelated within two generations. In the Exmoor Pony sample only horses with four generation long pedigrees were included and closely related individuals (full sibs) were excluded. For Lipizzan, Noriker, Posavina and Bosnian Mountain Horse SNP data were available from previous studies $[17,18,20]$. The samples for Lipizzan, Shagya Arabian, Akhal Teke, Haflinger and Noriker were discussed and approved by the institutional Commission for Ethics and Animal Welfare, University of Veterinary Medicine, Vienna, protocol number: ETK-06/05/2015. The hair samples of Bosnian Mountain, Posavina and Gidran horses were collected during routine procedures for studbook registration by the Institute for Breeding and Health Care of Horses of the Veterinary Faculty, Ljubljana. The samples of Selle Francais, Purebred Arabian and French Trotter horses were collected in accordance with generalized scheme of preferences (GSP) guidelines and national legislation and the Exmoor Pony samples were approved by the Ethics Committee for Animal Experiments in Uppsala, Sweden (Number: C 121/14).

\subsection{SNP Genotyping}

The SNP genotypes of the 1476 horses were derived using the Affymetrix Axiom ${ }^{\mathrm{TM}}$ Equine genotyping array [3]. The chromosomal position of the SNPs was determined based on EquCab2 reference genome [31]. We did not consider SNPs positioned on the sex chromosomes (X: 28017 SNPs and Y: 1 SNP) and SNPs without known chromosomal position (30,864 SNPs). SNPs with more than $10 \%$ missing genotypes were excluded. This resulted in a total of 611,914 SNPs that passed quality control and were used for further genetic analyses.

\subsection{Population Stratification and ROH Analysis}

In order to illustrate the population structure, we applied a principal component analysis (PCA) based upon the genetic relationship matrix (G) with pairwise identities by state (IBS) between horses as provided by PLINK v.1.7 [32]. The PCA scatter plot was performed using the R-platform (www.r-project.org).

$\mathrm{ROH}$ segments were determined with an overlapping window approach implemented in PLINK v1.7 [32] based on the following settings: minimum SNP density was set to one SNP per $50 \mathrm{~kb}$, with a maximum gap length of $100 \mathrm{~kb}$. The final segments were called runs of homozygosity (ROH) if the minimum length of the homozygous segment was greater than $500 \mathrm{~kb}$ and constituted more than 80 homozygous SNPs, whilst one heterozygote and two missing genotypes were permitted within each segment.

The distribution of $\mathrm{ROH}$ segments across the genome was visualized using the R-package detectROHs (www.r-project.org). Putative $\mathrm{ROH}$ islands were determined based on overlapping homozygous regions, shared by more than $50 \%$ of studied horses within each breed [12]. $\mathrm{ROH}$ islands which occurred only in one single breed were defined as "breed-specific" or "private". Resulting ROH islands were checked for overlaps between breeds, whereas no threshold for the minimal overlapping length size was applied.

Further statistical analyses, graphical representations and data preparation were performed using the software package SAS v.9.1 [33]. In order to provide a general overview, we plotted all chromosomes and illustrated length and position of $\mathrm{ROH}$ islands with boxes and pinpointed location of genes as vertical lines with either: (a) known functions, (b) associated with phenotypes in horses, (c) highlighted in selection signature studies, (d) with singular occurrence in $\mathrm{ROH}$ islands, and (e) genes, highlighted by GO analysis. 


\subsection{Gene Ontology Analysis}

The equine Ensembl database EquCab2 was used to identify genes located in $\mathrm{ROH}$ islands, available at www.ensembl.org. For the determination of gene ontology (GO) terms and KEGG (Kyoto Encyclopaedia of Genes and Genomes) pathways of identified annotated genes, the open source database for annotation, visualization and integrated discovery (DAVID) v6.8 package [34] was used. For the GO analysis the equine annotation file as background and a significance threshold of $p<0.05$, correcting for multiple testing applying Bonferroni-Holm test, were chosen.

\section{Results}

\subsection{Population Stratification}

The population structure of the studied horse breeds was ascertained with a PCA scatter plot as shown in Figure 2. Based upon the genetic pairwise identity-by-state (IBS) distance the first principal component 1 (PC1), accounting for $36 \%$ of the total variance, divided the 12 breeds into two main groups: (a) draught horse and Pony breeds (Noriker, Haflinger, Posavina and Exmoor Pony) and (b) performing and oriental breeds (Purebred Arabians, Shagya Arabians, Akhal Teke, Gidran, Selle Francais, French Trotter, Lipizzan and Bosnian Mountain Horse). Principal component 2 (PC2), accounting for $3 \%$ of the total variance, clearly separated the Lipizzan horses from the other breeds and simultaneously provided a fine-scale population structure of the oriental breeds (Purebred Arabian, Shagya Arabian, Gidran and Akhal Teke) by dividing them from the French Trotter and Selle Francais, whilst the latter two showed a high level of genetic relatedness. Visualization of PC1 versus PC3 (accounting for $1 \%$ of the total variance) illustrated the genetic relationship between the breeds and highlighted that the draught horse breeds gradually overlap along PC1 in direction from heavy to lighter type and geographically from North to South (Noriker, Haflinger, Posavina), whilst the Bosnian Mountain Horse built the hub to the oriental breed cluster. Compared to PC2, Exmoor Pony built a distinct cluster on PC3, whilst the Lipizzan horses were allocated next to Purebred Arabian and Shagya Arabian. Furthermore, it can be noticed that the draught horses were clearly divided along small to bigger size (Posavina, Haflinger, Noriker).
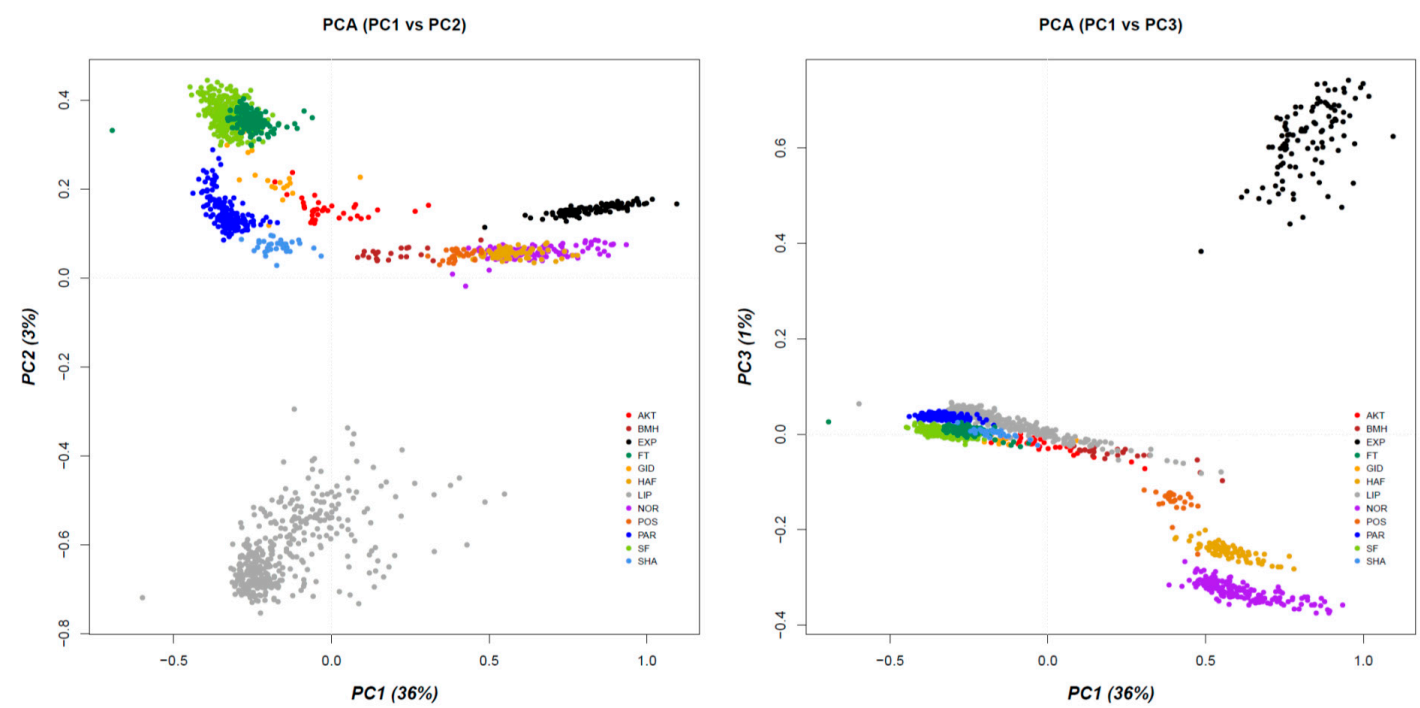

Figure 2. Principal component analysis (PCA) scatterplot illustrating the population stratification of 1,476 horses originating from 12 breeds. On the left visualization of PC1 versus PC2, together explaining $39 \%$ of genetic variance, and on the right visualization of $\mathrm{PC} 1$ versus $\mathrm{PC} 3$ together explaining $37 \%$ of variation, are presented. (AKT $=$ Akhal Teke, $\mathrm{BMH}=$ Bosnian Mountain Horse, EXP = Exmoor Pony, FT $=$ French Trotter, GID = Gidran, HAF $=$ Haflinger, LIP = Lipizzan, NOR = Noriker, POS = Posavina, $\mathrm{PAR}=$ Purebred Arabian, $\mathrm{SF}=$ Selle Francais and SHA = Shagya Arabian). 


\section{2. $R O H$ Island Pattern and Distribution}

Mean genome length covered by runs of homozygosity $\left(\mathrm{S}_{\mathrm{ROH}}\right)$ ranged on population level from 192.7 Mb to 506.1 Mb (Table 2). The highest values were assigned to the Exmoor Pony (506.1 Mb), the Arabian group (Purebred Arabian-368.1 Mb, Shagya Arabian-355.1 Mb, Gidran-321.9 Mb) and the French Trotter (352.8 Mb).

Table 2. Mean genome length covered by runs of homozygosity $\mathrm{S}_{\mathrm{ROH}}$ values (in $\mathrm{Mb}$ ), total length of overlapping homozygous regions ( $\mathrm{ROH}$ islands) (in $\mathrm{Mb}$ ), number of $\mathrm{ROH}$ islands and number of annotated genes within $\mathrm{ROH}$ islands per breed and number of private $\mathrm{ROH}$ islands per breed.

\begin{tabular}{|c|c|c|c|c|c|}
\hline Breed & $\mathrm{S}_{\mathrm{ROH}} \mathrm{Mb}$ & $\begin{array}{c}\text { Sum ROH } \\
\text { Islands } \mathrm{Mb}\end{array}$ & n ROH Islands & $\begin{array}{c}\text { n Genes in } \\
\text { ROH Islands }\end{array}$ & $\begin{array}{l}\text { n Private ROH } \\
\text { Islands }\end{array}$ \\
\hline Exmoor Pony & 506.1 & 24.5 & 33 & 171 & $\begin{array}{l}28 \text { on } \\
\text { ECA1,2,3,4,6,16,18,19, } \\
22,23,28,30\end{array}$ \\
\hline French Trotter & 352.8 & 20.5 & 22 & 156 & $\begin{array}{l}14 \text { on } \\
\text { ECA2, } 4,6,7,8,9,15,23\end{array}$ \\
\hline Selle Francais & 297.1 & 2.1 & 5 & 8 & 1 on ECA1 \\
\hline Lipizzan & 297.0 & 1.9 & 5 & 23 & 1 on ECA14 \\
\hline Noriker & 215.5 & 5.0 & 5 & 50 & 1 on ECA11 \\
\hline Posavina & 192.7 & 2.2 & 5 & 16 & 1 on ECA28 \\
\hline Haflinger & 279.7 & 4.9 & 5 & 60 & - \\
\hline Gidran & 321.9 & 19.2 & 30 & 143 & $\begin{array}{l}18 \text { on } \\
\text { ECA2,3,4,6,9,14,17, } \\
22,25,27,28\end{array}$ \\
\hline $\begin{array}{l}\text { Purebred } \\
\text { Arabian }\end{array}$ & 368.1 & 15.5 & 19 & 141 & 5 on ECA2, $4,5,14,22$ \\
\hline Shagya Arabian & 355.1 & 22.4 & 32 & 242 & $\begin{array}{l}23 \text { on } \\
\text { ECA1,2,6,8,9,11,15,16, } \\
18,19,23,25\end{array}$ \\
\hline Akhal Teke & 246.1 & 4.8 & 9 & 90 & 4 on ECA1,11,19 \\
\hline $\begin{array}{l}\text { Bosnian } \\
\text { Mountain Horse }\end{array}$ & 296.3 & 4.2 & 10 & 35 & 4 on ECA3, $6,11,23$ \\
\hline
\end{tabular}

Medium $\mathrm{S}_{\mathrm{ROH}}$ levels around $290 \mathrm{Mb}$ were found in the Lipizzan, Selle Francais, Haflinger and Bosnian Mountain Horse, followed by the Akhal Teke $(246.1 \mathrm{Mb})$ and Noriker $(215.5 \mathrm{Mb})$. The lowest values were identified in the Posavina $(192.7 \mathrm{Mb})$. The highest number and total length of overlapping homozygous regions were expressed by Exmoor Pony (33 islands, $24.5 \mathrm{Mb}$ ) followed by Shagya Arabian (32 islands, 22.4 Mb), Gidran (30 islands, $19.2 \mathrm{Mb}$ ) and French Trotter (22 islands, $20.5 \mathrm{Mb}$ ) (Table 2). Low numbers of $\mathrm{ROH}$ islands were detected in Lipizzan (5 islands, $1.9 \mathrm{Mb}$ ), Selle Francais (five islands, $2.1 \mathrm{Mb}$ ) and Posavina (five islands, $2.2 \mathrm{Mb}$ ) (Table 2, Supplementary File 1). In general, the total $\mathrm{ROH}$ island length per breed was consistent with its mean $\mathrm{S}_{\mathrm{ROH}}$, except for the Lipizzan and Selle Francais, where the length of five overlapping homozygous regions comprised $1.9 \mathrm{Mb}$, respectively $2.1 \mathrm{Mb}$ in contrast to a medium $\mathrm{S}_{\mathrm{ROH}}$ of $297 \mathrm{Mb}$ (Table 2).

From a total of 180 identified $\mathrm{ROH}$ islands 100 were private for a specific breed (Table 2), whilst all other islands overlapped in 36 genomic regions and were shared by at least two breeds (Table 3 ). High numbers of private ROH islands were present in Exmoor Pony (28 out of 33), Shagya Arabian (23 out of 32), Gidran (18 out of 30) and in French Trotter (14 out 22) (Table 3). Low numbers of breed specific $\mathrm{ROH}$ islands were determined in Lipizzan, Noriker, Posavina and Selle Francais where one 
out of five homozygous regions was solely found within the respective breed. Within Haflinger no private islands were detected, as all islands overlapped with homozygous regions of other breeds.

Table 3. Overlaps of runs of homozygosity $(\mathrm{ROH})$ islands (begin and end in $\mathrm{Mb}$ ) between breeds and annotated genes.

\begin{tabular}{|c|c|c|c|c|}
\hline Chr. & Begin & End & $\begin{array}{l}\text { Breed Shared ROH } \\
\text { Islands }\end{array}$ & $\begin{array}{l}\text { Annotated Genes within } \\
\text { ROH Islands }\end{array}$ \\
\hline 1 & $148,443.474$ & $148,516.796$ & $\begin{array}{l}\text { Akhal Teke, Bosnian } \\
\text { Mountain Horse }\end{array}$ & EIF2AK4 \\
\hline 3 & $34,386.385$ & $34,732.351$ & Akhal Teke, Haflinger & $\begin{array}{l}\text { KLHDC4, SLC7A5, CA5A, } \\
\text { BANP }\end{array}$ \\
\hline 3 & $36,047.262$ & $36,548.306$ & $\begin{array}{l}\text { Gidran, Haflinger, } \\
\text { Purebred Arabian }\end{array}$ & $\begin{array}{l}\text { CDK10, SPATA2L, ZNF276, } \\
\text { VPS9D1, FANCA, SPIRE2, } \\
\text { TCF25, DBNDD1, GAS8, } \\
\text { MC1R, DEF8 }\end{array}$ \\
\hline 3 & $37,179.496$ & $38,127.255$ & $\begin{array}{l}\text { Gidran, Haflinger, } \\
\text { Purebred Arabian }\end{array}$ & $\begin{array}{l}\text { MANBA, NFKB1, SLC } 39 A 8 \\
\text { BANK1 }\end{array}$ \\
\hline 3 & $105,767.304$ & $105,832.553$ & Exmoor Pony, Noriker & NCAPG, DCAF16 \\
\hline 3 & $118,669.793$ & $118,769.903$ & $\begin{array}{l}\text { Lipizzan, Shagya } \\
\text { Arabian, Purebred } \\
\text { Arabian }\end{array}$ & UVSSA, MAEA \\
\hline 3 & $118,809.979$ & $118,893.880$ & $\begin{array}{l}\text { Lipizzan, Shagya } \\
\text { Arabian, Purebred } \\
\text { Arabian }\end{array}$ & СТВP1 \\
\hline 3 & $118,659.800$ & $119,479.623$ & $\begin{array}{l}\text { Shagya Arabian, } \\
\text { Purebred Arabian }\end{array}$ & $\begin{array}{l}\text { UVSSA, MAEA, CTBP1, } \\
\text { SPON2, FGFRL1, IDUA, } \\
\text { SLC26A1, DGKQ, TMEM175, } \\
\text { GAK, CPLX1, PCGF3, } \\
\text { SLC49A3, MYL5, ATP5ME, } \\
\text { PDE6B, PIGG }\end{array}$ \\
\hline 4 & $15,163.634$ & $15,817.917$ & $\begin{array}{l}\text { Akhal Teke, French } \\
\text { Trotter }\end{array}$ & $\begin{array}{l}\text { NUDCD3, NPC1L1, DDX56, } \\
\text { TMED4, OGDH, ZMIZ2, } \\
\text { H2AFV, MYO1G, CCM2, } \\
\text { TBRG4, RAMO3 }\end{array}$ \\
\hline 4 & $50,883.038$ & $50,904.590$ & Gidran, Shagya Arabian & HDAC9 \\
\hline 4 & $52,692.165$ & $52,840.002$ & Gidran, French Trotter & $A B C B 5$ \\
\hline 6 & $29,424.361$ & $30,040.425$ & $\begin{array}{l}\text { Bosnian Mountain Horse, } \\
\text { Posavina, Selle Francais }\end{array}$ & ERC1, RAD52, WNK1, NINJ2 \\
\hline 6 & $41,240.508$ & $41,843.164$ & Gidran, French Trotter & GRIN2B \\
\hline 6 & $81,156.975$ & $81,795.964$ & Exmoor Pony, Gidran & $H M G A 2, L L P H, I R A K 3$ \\
\hline 7 & $39,587.420$ & $41,127.737$ & $\begin{array}{l}\text { French Trotter, Purebred } \\
\text { Arabian, Shagya Arabian }\end{array}$ & NTM, OPCML \\
\hline 7 & $48,157.328$ & $48,930.905$ & French Trotter, Haflinger & $\begin{array}{l}\text { ACP5, ELOF1, CNN1, ECSIT, } \\
\text { ZNF653, PRKCSH, RGL3, } \\
\text { EPOR, SWSAP1 }\end{array}$ \\
\hline 7 & $50,167.155$ & $50,932.454$ & $\begin{array}{l}\text { French Trotter, Purebred } \\
\text { Arabian }\end{array}$ & ZNF699 \\
\hline
\end{tabular}


Table 3. Cont

\begin{tabular}{|c|c|c|c|c|}
\hline Chr. & Begin & End & $\begin{array}{l}\text { Breed Shared } \mathrm{ROH} \\
\text { Islands }\end{array}$ & $\begin{array}{l}\text { Annotated Genes within } \\
\text { ROH Islands }\end{array}$ \\
\hline 9 & $31,329.939$ & $32,034.084$ & $\begin{array}{l}\text { Purebred Arabian, } \\
\text { Shagya Arabian }\end{array}$ & PCMTD1, PXDNL \\
\hline 9 & $44,411.007$ & $44,562.960$ & $\begin{array}{l}\text { Purebred Arabian, } \\
\text { Shagya Arabian, Exmoor } \\
\text { Pony, (Haflinger) }\end{array}$ & KCNS2 \\
\hline 9 & $75,054.137$ & $75,434.658$ & Noriker, Posavina & ZFAT \\
\hline 11 & $21,801.064$ & $21,938.218$ & $\begin{array}{l}\text { Purebred Arabian, } \\
\text { Shagya Arabian }\end{array}$ & $\begin{array}{l}\text { KRT28, KRT27, KRT26, } \\
\text { KRT25, KRT24 }\end{array}$ \\
\hline 11 & $21,966.387$ & $22,416.682$ & $\begin{array}{l}\text { Akhal-Teke, Purebred } \\
\text { Arabian, Shagya Arabian }\end{array}$ & $\begin{array}{l}\text { SMARCE1, CCR7, TNS4, } \\
\text { GFBP4, TOP2A, RARA, } \\
\text { CDC6, WIPF2, RAPGEFL1, } \\
\text { CASC3, MSL1, NR1D1, } \\
\text { THRA }\end{array}$ \\
\hline 11 & $24,285.730$ & $24,816.254$ & $\begin{array}{l}\text { Noriker, Posavina, } \\
\text { Gidran, Lipizzan }\end{array}$ & $\begin{array}{l}\text { HOXB1, HOXB2, HOXB3, } \\
\text { HOXB5, HOXB6, HOXB7, } \\
\text { HOXB8, HOXB13, TTLL6 }\end{array}$ \\
\hline 11 & $24,793.573$ & $24,822.752$ & $\begin{array}{l}\text { Noriker, Posavina, } \\
\text { Bosnian Mountain } \\
\text { Horse, Haflinger, Gidran }\end{array}$ & CALCOCO2 \\
\hline 11 & $26,117.473$ & $27,008.802$ & $\begin{array}{l}\text { Gidran, Purebred } \\
\text { Arabian }\end{array}$ & $\begin{array}{l}\text { ACSF2, CHAD, RSAD1, } \\
\text { MYCABPAP, EPN3, } \\
\text { SPATA20, CACNA1G, } \\
\text { ABCC3, ANKRD40, LUC7L3, } \\
\text { ANKRD40CL, WFIKKN2, } \\
\text { TOB1, SPAG9, NME1-NME2, } \\
\text { MBTD1, UTP18 }\end{array}$ \\
\hline 11 & $27,363.048$ & $28,118.531$ & $\begin{array}{l}\text { Gidran, Purebred } \\
\text { Arabian }\end{array}$ & CA10 \\
\hline 11 & $29,747.581$ & $30,078.455$ & $\begin{array}{l}\text { Bosnian Mountain Horse, } \\
\text { Exmoor Pony, Noriker, }\end{array}$ & STXBP4, COX11, HLF, MMD \\
\hline 11 & $30,690.860$ & $30,774.494$ & $\begin{array}{l}\text { Bosnian Mountain } \\
\text { Horse, Haflinger, } \\
\text { Lipizzan, Noriker }\end{array}$ & ANKFN1 \\
\hline 11 & $31,062.702$ & $31,250.934$ & $\begin{array}{l}\text { Lipizzan, Noriker, } \\
\text { Purebred Arabian, } \\
\text { Shagya Arabian }\end{array}$ & C11H17orf67 \\
\hline 11 & $31,062.702$ & $31,810.316$ & $\begin{array}{l}\text { Purebred Arabian, } \\
\text { Shagya Arabian, } \\
\text { Lipizzan }\end{array}$ & $\begin{array}{l}\text { C11H17orf67, DGKE, COIL, } \\
\text { SCPEP1, AKAP1, MSI2 }\end{array}$ \\
\hline 15 & $79,489.871$ & $79,964.006$ & $\begin{array}{l}\text { French Trotter, Shagya } \\
\text { Arabian }\end{array}$ & - \\
\hline 18 & $10,733.279$ & $11,116.742$ & $\begin{array}{l}\text { Bosnian Mountain } \\
\text { Horse, Purebred Arabian }\end{array}$ & $I N H B B, R A L B, E P B 41 L 5$ \\
\hline 18 & $49,323.427$ & $49,940.945$ & $\begin{array}{l}\text { French Trotter, Gidran, } \\
\text { Selle Francais, Shagya } \\
\text { Arabian }\end{array}$ & $\begin{array}{l}\text { SSB, METTL5, UBR3, } \\
\text { MYO3B }\end{array}$ \\
\hline 19 & $50,554.541$ & $50,890.075$ & $\begin{array}{l}\text { Gidran, Purebred } \\
\text { Arabian }\end{array}$ & $C B L B, A L C A M$ \\
\hline 23 & $54,975.635$ & $54,984.719$ & French Trotter, Gidran & FGD3 \\
\hline 25 & $6,409.342$ & $6,812.785$ & Lipizzan, Gidran & NR4A3, STX17, ERP44, INVS \\
\hline
\end{tabular}


The Exmoor Pony exhibited no common homozygous region with Akhal Teke and the performing breeds. The $\mathrm{ROH}$ islands of the Bosnian Mountain Horse did not match with those of the Shagya Arabians and those of the performance breeds, and the French Trotter had no common island with Lipizzan, draught horse breeds, Exmoor Pony and Bosnian Mountain Horse. A summary for all ROH islands per breed is presented in Supplementary File 1 and Supplementary File 2.

The $\mathrm{ROH}$ islands were unequally distributed across the genome. Nine chromosomes were $\mathrm{ROH}$ island cold spots. Among all breeds no $\mathrm{ROH}$ islands were located on the following chromosomes: ECA10, ECA12, ECA13, ECA20, ECA21, ECA24, ECA26, ECA29 and ECA31.

ECA11 can be characterized as a ROH island hot spot (Figure 3), as all breeds except French Trotter and Selle Francais had at least one up to five ROH islands located in this region (ECA11: 20-37 Mb). Six islands were breed-specific in: Akhal Teke, Noriker, Shagya Arabian and Bosnian Mountain Horse. The overlapping homozygous regions (Table 3) can be assigned into four different groups: a) the orientalized group, including Akhal Teke, Purebred Arabian, Shagya Arabian from $21.8 \mathrm{Mb}$ to $22.4 \mathrm{Mb}$, and Purebred Arabian and Gidran from $26.1 \mathrm{Mb}$ to $28.1 \mathrm{Mb}, \mathrm{b}$ ) breeds originating from the geographical region of the former Austro-Hungarian empire at position 24.2-24.8 Mb, c) autochthonous breeds (Bosnian Mountain Horse, Exmoor Pony and Noriker) with an overlapping homozygous region between $29.7 \mathrm{Mb}$ and $30.1 \mathrm{Mb}$, d) mixed group including Noriker, Bosnian Mountain Horse, Exmoor Pony, Haflinger, Shagya Arabian, Purebred Arabian and Lipizzan horses with overlapping $\mathrm{ROH}$ islands from $30.6 \mathrm{Mb}$ to $31.8 \mathrm{Mb}$ (Figure 3).

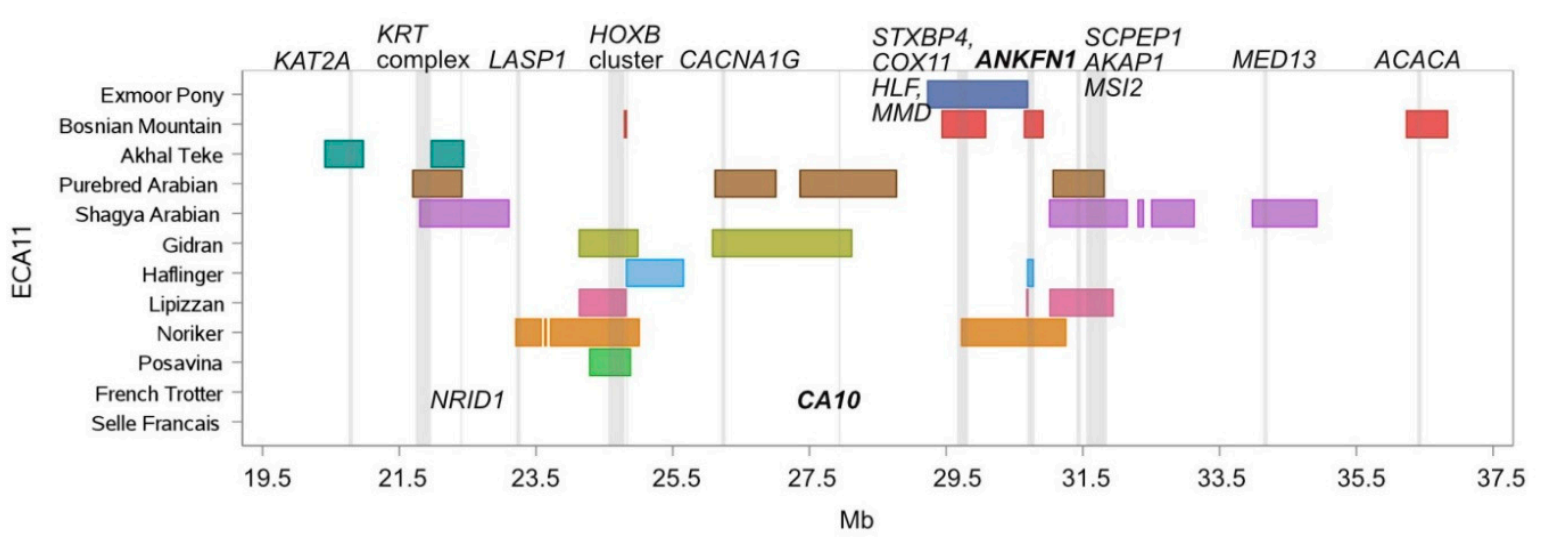

Figure 3. $\mathrm{ROH}$ islands on ECA11 between $19.5 \mathrm{Mb}$ and $37.5 \mathrm{Mb}$. Location and length of $\mathrm{ROH}$ islands (shared by more than $50 \%$ of individuals per breed) per breed are illustrated as horizontal boxes, location of genes of specific interest are indicated as vertical lines.

The $\mathrm{ROH}$ islands of the Arabian breeds overlapped in a genomic region where several members of the KRT complex are located (Table 2). The gene LASP1 (LIM and SH3 protein 1), associated with body size [35], was found in a $235 \mathrm{~kb}$ long private $\mathrm{ROH}$ island of the Noriker, which harbored nine additional genes. A gene group with fundamental impact on embryonic morphogenesis is the homeobox $\mathrm{B}$ (HOXB) cluster [36]. This gene cluster was present in up to $1.2 \mathrm{Mb}$ long ROH islands on ECA11 in Noriker, Posavina, Lipizzan and Gidran (Figure 3). The autochthonous breeds (Exmoor Pony, Bosnian Mountain Horse and Noriker) shared a common homozygous region harboring the genes STXBP4 (syntaxin-binding protein 4), COX11 (cytochrome c oxidase copper chaperone COX11), HLF (HLF transcription factor), and $M M D$ (monocyte to macrophage differentiation associated). The islands of the Exmoor Pony and the Noriker exceeded in length up to the gene ANKFN1 (ankyrin repeat and fibronectin type III domain containing 1), which was also present in the ROH islands of Lipizzan, Bosnian Mountain Horses and Haflinger (Figure 3). The Arabian breeds and the Lipizzan overlapped in a region containing among six annotated genes, the genes SCPEP1 (serine carboxypeptidase 1), AKAP1 (A-kinase anchoring protein 1) and MSI2 (musashi RNA binding protein 2). 
A second $\mathrm{ROH}$ island hot spot was identified on ECA3 in several genomic regions around the genes KLHDC4 (Kelch domain containing 4), MC1R (melanocortin 1 receptor), BANK1 (B cell scaffold protein with ankyrin repeats 1) and UVSSA (UV stimulated scaffold protein A) for breeds derived or influenced by the oriental gene pool (Purebred Arabian, Shagya Arabian, Haflinger and Akhal Teke) (Figure 4). The longest island covered the gene MC1R and reached up to $2.2 \mathrm{Mb}$ length in the Haflinger sample (Figure 4). The Arabian breeds exhibited an ROH island at the UVSSA locus. Around the LCORL/NCAPG locus (ligand dependent nuclear receptor corepressor like/non-SMC condensin I complex subunit G), which was associated with body size [35], another homozygous region was shared by the Exmoor Pony and the Noriker horse. Within the Gidran sample, a private island containing PPARGC1A (peroxisome proliferator-activated receptor gamma, coactivator 1 alpha), a gene undergone positive selection in Thoroughbreds [1], was detected.

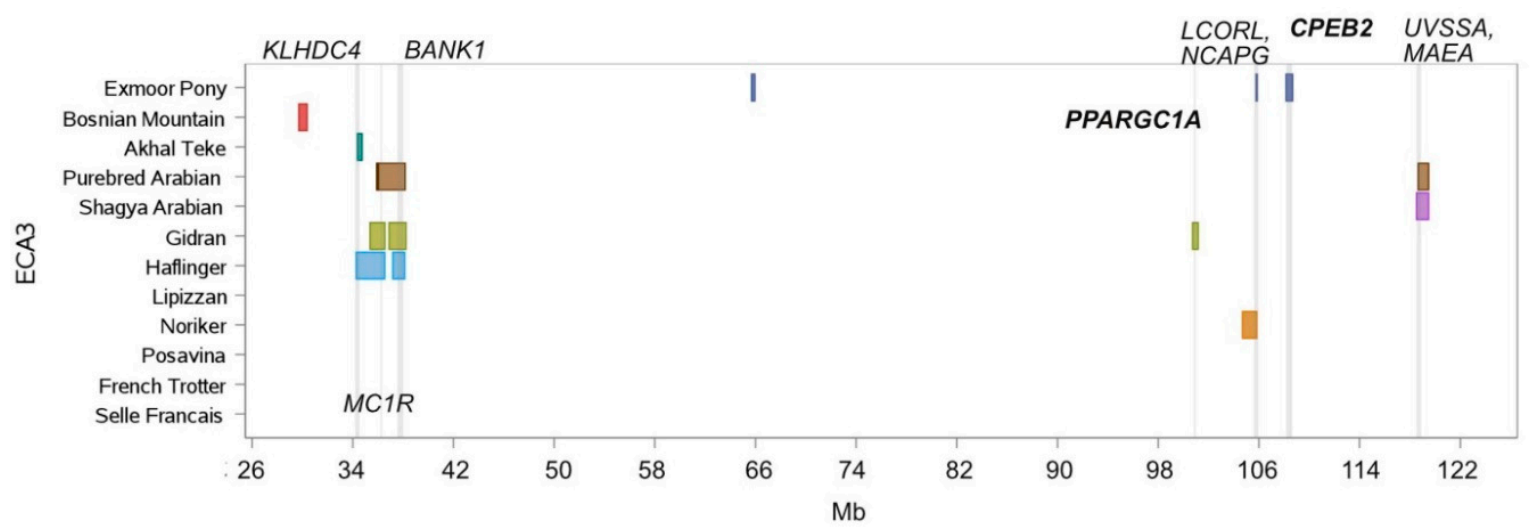

Figure 4. $\mathrm{ROH}$ islands on ECA3 between $26 \mathrm{Mb}$ and $122 \mathrm{Mb}$. Location and length of $\mathrm{ROH}$ islands (shared by more than $50 \%$ of individuals per breed) per breed are illustrated as horizontal boxes, location of genes of specific interest are indicated as vertical lines.

$\mathrm{ROH}$ islands on ECA4 (Supplementary File 2) and ECA7 (Figure 5) were ROH island hot spots predominantly for the oriental group (Purebred Arabian, Shagya Arabian, Gidran and Akhal Teke) and the two performing breeds Selle Francais and French Trotter. The longest homozygous region was found in the French Trotter on ECA7, where four ROH islands were located between $39.6 \mathrm{Mb}$ and $52.5 \mathrm{Mb}$, comprising together a length of $10.1 \mathrm{Mb}$ which is comparable to $50 \%$ of the total length of $\mathrm{ROH}$ islands in this breed (Figure 5). Within the same region the Purebred Arabian, Shagya Arabian, Selle Francais and Haflinger overlapped with up to two (Purebred Arabian) shorter ROH islands.

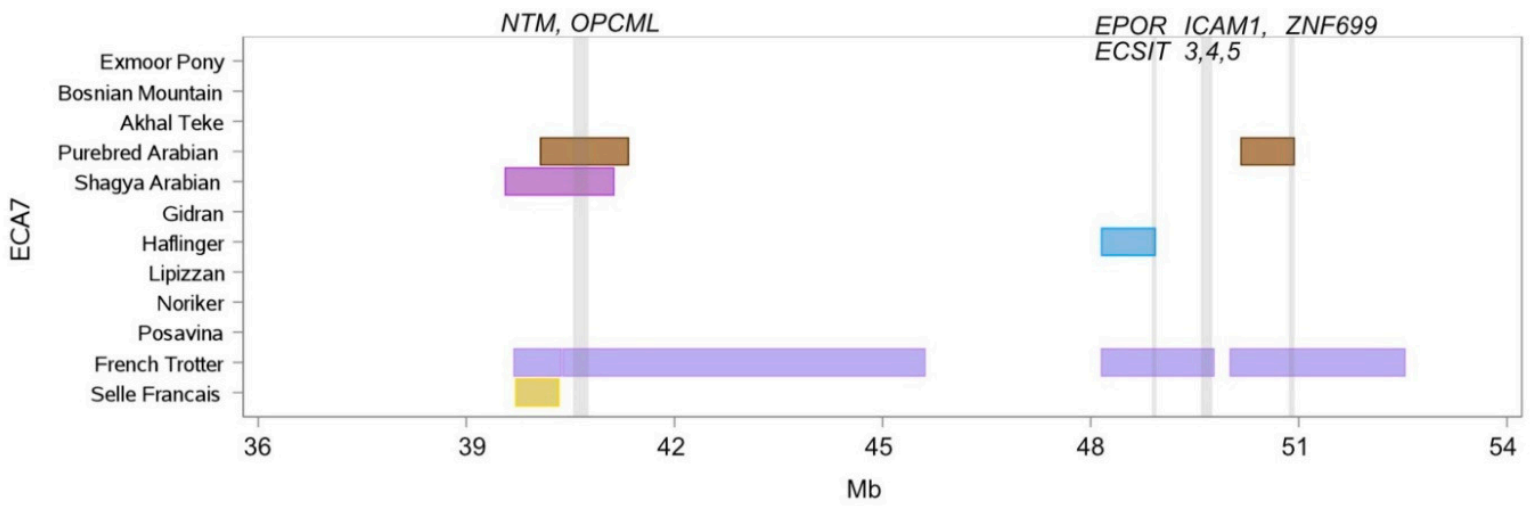

Figure 5. $\mathrm{ROH}$ islands on ECA7 between $36 \mathrm{Mb}$ and $54 \mathrm{Mb}$. Location and length of $\mathrm{ROH}$ islands (shared by more than $50 \%$ of individuals per breed) per breed are illustrated as horizontal boxes, location of genes of specific interest are indicated as vertical lines. 
The Selle Francais had, although characterized by a medium genome-wide $\mathrm{S}_{\mathrm{ROH}}$ of $297 \mathrm{Mb}$, only five $\mathrm{ROH}$ islands in total. The island on ECA7 completely overlapped with the French Trotter specific island at the identical position but not in frequency, as only a small fragment exceeded the 50\% threshold (Supplementary File 3). A homozygous region at position 39.5-41.1 Mb was also present in the Purebred and Shagya Arabian and harbored the genes NTM (neurotrimin) and OPCML (opioid-binding protein/cell adhesion molecule). Out of $22 \mathrm{ROH}$ islands 14 were private within the French Trotter. Among them was an island on ECA23, which harbored the gene DMRT3 (doublesex and mab-3 related transcription factor 3) (Supplementary File 2). A mutation in DMRT3 is responsible for the ability to perform alternate gaits [37]. This gene/island was only detected for the French Trotter within the entire sample.

The autochthonous breeds (Exmoor Pony, Noriker, Posavina and Bosnian Mountain Horse) shared three overlapping $\mathrm{ROH}$ islands located on three different chromosomes. Besides the aforementioned island on ECA3 containing the gene NCAPG (shared by Noriker and Exmoor Pony) (Figure 4), and the island on ECA11 harboring the genes STXBP4, COX11, HLF, and MMD (shared by Noriker, Exmoor Pony and Bosnian Mountain Horse) (Figure 3), another common island on ECA9 was identified (Supplementary File 2). This island at position 75.0-75.4 Mb contains the gene ZFAT (zinc finger and AT-hook domain) and it was present in the Noriker and Posavina sample (Table 3).

The high genetic distance of the Exmoor Pony to the other breeds was also evident in the $\mathrm{ROH}$ island pattern, where 28 from 33 islands were solely detected within this breed (Table 2). ECA22 was an $\mathrm{ROH}$ island hot spot for this British Pony breed covering eight islands between $24.5 \mathrm{Mb}$ and $46.9 \mathrm{Mb}$, which comprised together a length of $4.7 \mathrm{Mb}$ (Figure 6). The island between $24.5 \mathrm{Mb}$ and $25.5 \mathrm{Mb}$ harbored among 14 other annotated genes, the gene ASIP (agouti-signaling-protein) responsible for bay coat color [38].

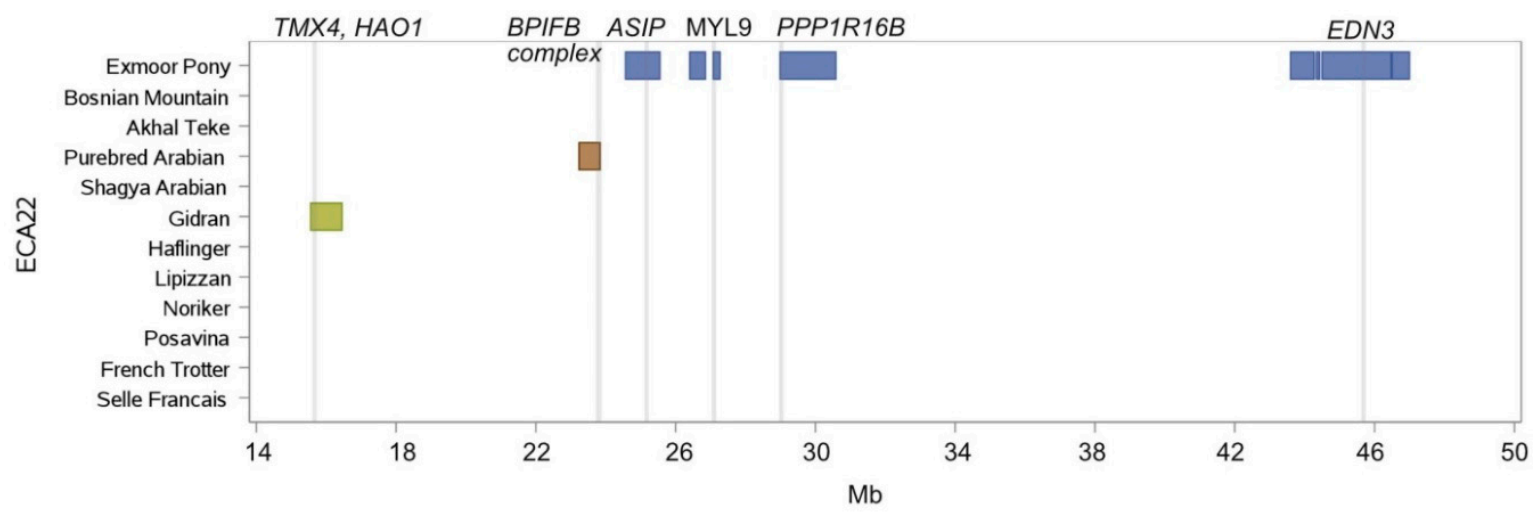

Figure 6. $\mathrm{ROH}$ islands on ECA22 between $14 \mathrm{Mb}$ and $50 \mathrm{Mb}$. Location and length of $\mathrm{ROH}$ islands (shared by more than $50 \%$ of individuals per breed) per breed are illustrated as horizontal boxes, location of genes of specific interest are indicated as vertical lines.

Beside the aforementioned chromosomes ECA3, ECA4, ECA7, ECA9, and ECA11, ROH islands overlapped in genomic regions on seven further chromosomes (ECA1, ECA6, ECA15, ECA18, ECA19, ECA23, ECA25). Akhal Teke and Bosnian Mountain Horse shared one homozygous region on ECA1 at position $148.4 \mathrm{Mb}-148.1 \mathrm{Mb}$ enclosing one single gene (EIF2AK4, eukaryotic translation initiation factor 2 alpha kinase 4). On ECA6 the Posavina, the Bosnian Mountain Horse and the Selle Francais shared an island containing the genes ERC1 (ELKS/RAB6-interacting/CAST family member 1), RAD52 (RAD52 homolog), WNK1 (WNK lysine deficient protein kinase 1) and NINJ2 (ninjurin 2) (Figure 7). The gene GRIN2B (glutamate ionotropic receptor NMDA type subunit 2B) was located in an island of the French Trotter and the Gidran. On the same chromosome the Exmoor Pony exhibited together with the Gidran a $\mathrm{ROH}$ island, harboring the genes HMGA2 (high mobility group AT-hook 2), LLPH 
(LLP homolog, long-term synaptic facilitation factor), IRAK3 (interleukin 1 receptor associated kinase 3) and HELB (DNA helicase B) (Figure 7).

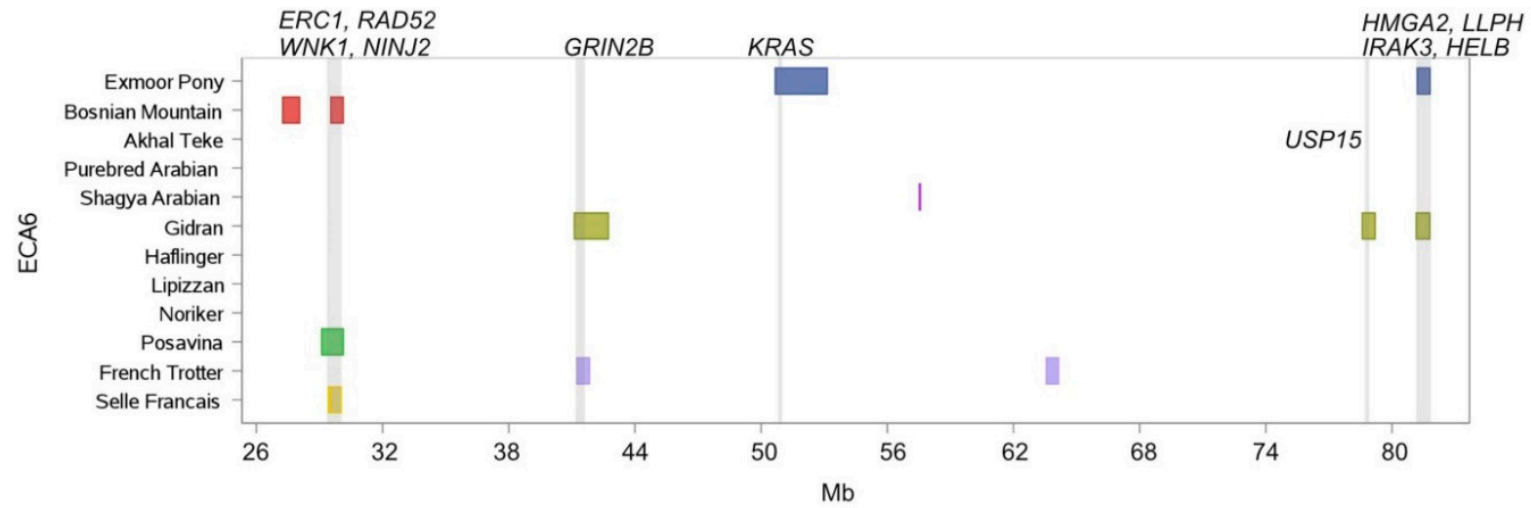

Figure 7. $\mathrm{ROH}$ islands on ECA6 between $26 \mathrm{Mb}$ and $80 \mathrm{Mb}$. Location and length of $\mathrm{ROH}$ islands (shared by more than $50 \%$ of individuals per breed) per breed are illustrated as horizontal boxes, location of genes of specific interest are indicated as vertical lines.

On ECA18 the French Trotter, Selle Francais, Gidran and Shagya Arabian shared a ROH island at position $49.3 \mathrm{Mb}-49.4 \mathrm{Mb}$ containing the genes $S S B$ (small RNA binding exonuclease protection factor La), METTL5 (methyltransferase like 5), UBR3 (ubiquitin protein ligase E3 component n-recognin 3), and $M Y O 3 B$ (myosin IIIB). Furthermore, the genes RALB (Ras-like G-protein) and INHBB (Inhibin subunit beta B) were identified in a shared homozygous region of the Bosnian Mountain Horse and Purebred Arabian (Figure 8).

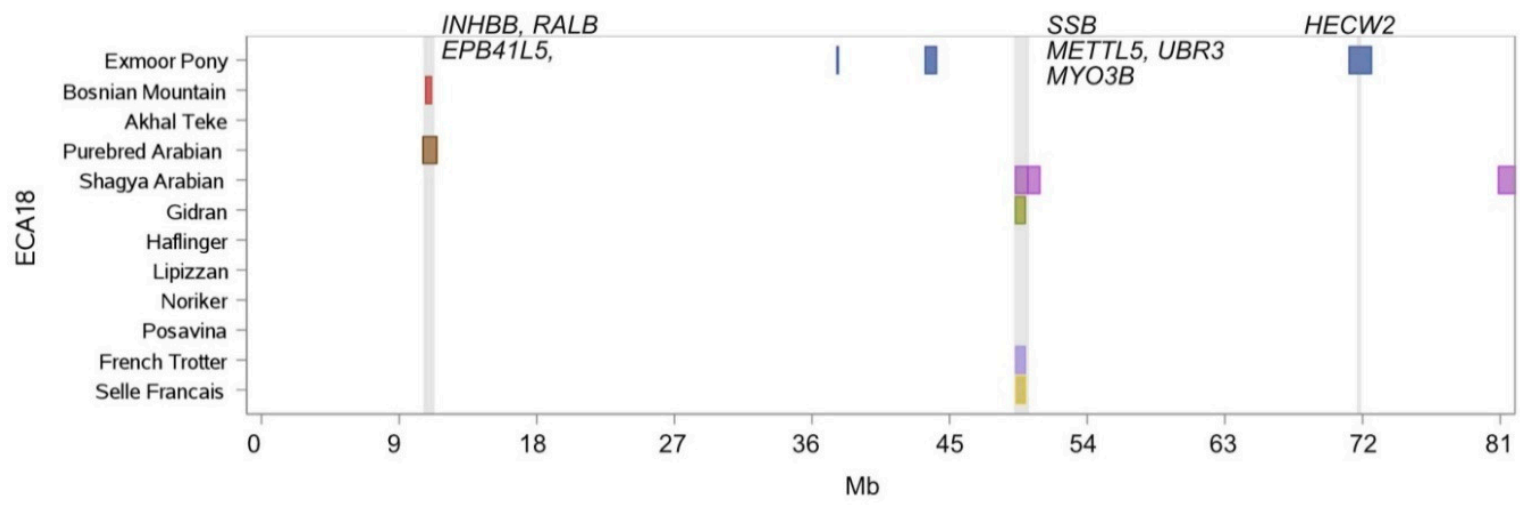

Figure 8. $\mathrm{ROH}$ islands on ECA18 between $1 \mathrm{Mb}$ and $81 \mathrm{Mb}$. Location and length of $\mathrm{ROH}$ islands (shared by more than $50 \%$ of individuals per breed) per breed are illustrated as horizontal boxes, location of genes of specific interest are indicated as vertical lines.

\subsection{Genotype Frequencies of Genes Involved in Coat Color and Body Size}

In six breeds of the dataset, coat color represents an explicit breeding objective. In the Gidran and Haflinger, chestnut coat color is fixed. The desired color for the Exmoor Pony is brown combined with mealy areas around the eyes, muzzle, elbow and flanks. Lipizzan horses have been selected for their gray color for 150 years and the frequency of gray phenotypes reaches up to 98\% [18] and the breeding program of the Noriker horse is based upon the selection for six different coat colors (bay, black, chestnut, leopard, roan and tobiano).

We identified a $\mathrm{ROH}$ island containing $M C 1 R$, responsible for chestnut coat color, in the Gidran (1.1 Mb length), Haflinger (2.2 Mb length) and the Purebred Arabian (2.1 Mb length) samples. Genotype data for $M C 1 R$ was available and is summarized for each breed in Supplementary File 4 . All breeds with 
a high frequency of chestnut coat color had an additional ROH island on ECA3 (Figure 4), which was scalariform structured. The core ROH island harbored the genes NFKB1 (Nuclear factor NF-kappa-B p105 subunit), SLC39A8 (solute carrier family 39 member 8) and BANK1 and was embedded in an up to $2.1 \mathrm{Mb}$ long $\mathrm{ROH}$ island in Purebred Arabians. Highest frequencies (95\%) for this core island were observed in the Gidran. In the Gidran sample (100\% homozygous T/T on MC1R) an additional $\mathrm{ROH}$ island on ECA25 was identified, harboring the STX17 gene responsible for gray coat color. This homozygous region was $403.5 \mathrm{~kb}$ long and contained the genes STX17, NR4A3, ERP44 and INVS. Purebred and Shagya Arabian had a ROH island on ECA3 containing the genes MAEA (macrophage erythroblast attacher) () and UVSSA (Figure 4), which plays an important role in the nucleotide excision repair (NER) pathway responsible for the reparation of DNA damage caused by UV radiation [39]. From a previous study [18] we know, that the Lipizzan had an ROH island around UVSSA, which is too small to be detected with a $500 \mathrm{~kb}$ window. We extracted the four available SNPs within the UVSSA gene for the entire sample and revealed for two non-synonymous SNPs (AX-103191894 in intron 7 and AX-104669126 in intron 6 ) distinct genotype distributions between the breeds, corresponding with the geographical dispersion area of origin (Supplementary File 5).

Within the Exmoor Pony we further identified an ROH island on ECA22 containing among 14 annotated genes, the gene ASIP (agouti signaling protein) and an island on ECA1 harboring the genes $O C A 2$ and HERC2 (Supplementary File 2). OCA2/HERC2 were associated with eye pigmentation (blue, green, hazel eyes), lighter skin pigmentation, blond and red hair in humans [40].

The genome-wide ROH island scan revealed several loci (LCORL/NCAPG, ZFAT, LASP1 and HMGA2) associated with body size [35] and height at withers, back and croup length (ZFAT) [41]. Body size associated loci were embedded in islands of the draught horse breeds Noriker (LCORL/NCAPG, ZFAT and LASP1), Posavina (ZFAT) and in the Exmoor Pony (LCORL/NCAPG and HMGA2). Interestingly also in Gidran a $639 \mathrm{~kb}$ long $\mathrm{ROH}$ island containing HMGA2 together with the genes $L L P H$ and IRAK3 was identified. Three out of the four SNPs associated with body size according to Makvandi-Nejad et al. [35] are available on the applied genotyping array. From a previous study [17] we know that the majority of Noriker horses are homozygous for the "Big"-alleles of the SNPs near LCORL/NCAPG, ZFAT and LASP1 and that the Posavina horse shifts to the "small" allele of the LCORL/NCAPG gene. We extracted the three size associated SNPs for the Exmoor Pony and the Bosnian Mountain Horse, a breed that is known to be selected for a height at withers around $135 \mathrm{~cm}$ on a long term. The majority of Bosnian Mountain Horses (57-87\%) were homozygous for the "small" alleles in all three loci (Supplementary File 6). The Exmoor Pony was monomorphic for the "small" allele near the LCORL/NCAPG gene and $92 \%$ of horses were also homozygous for the "small" allele near ZFAT. Deviation from Hardy-Weinberg equilibrium was observed for the ZFAT locus in Exmoor Pony $(p>0.014)$ and revealed on-going selection towards small body size.

\subsection{Gene Ontology and Enrichment Analysis}

From the 91 breed specific GO terms and six KEGG pathways determined, 14 GO terms remained significant after correction for multiple testing in Noriker, Lipizzan, Posavina, Gidran, Shagya Arabian, Purebred Arabian, and French Trotter. A detailed description of enrichment analysis for each breed is given in Supplementary File 7. Several GO terms were shared by more than one breed (Table 4). High significance levels (Bonferroni adjusted $p$-value $<0.05$ ) were reached for the $\mathrm{GO}$ terms anterior/posterior pattern specification (GO:0009952), embryonic skeletal system morphogenesis (GO:0048704) and sequence-specific DNA binding (GO:0043565), mainly based upon the HOXB-cluster in the breeds Gidran, Lipizzan, Posavina and Noriker. For Purebred and Shagya Arabian, several members of the KRT-complex retained the term intermediate filament (GO:0005882) (Table 4). 
Table 4. Gene Ontology terms and Kyoto Encyclopaedia of Genes and Genomes (KEGG) pathways, which were shared by two or more breeds $(\mathrm{BH} p$-value $=$ Bonferroni adjusted $p$-value).

\begin{tabular}{|c|c|c|c|c|}
\hline GO Biological Process & Breeds Sharing Term & $p$-value & Genes & BH $p$-Value \\
\hline $\begin{array}{l}\text { GO:0009952 anterior/ } \\
\text { posterior pattern } \\
\text { specification }\end{array}$ & $\begin{array}{l}\text { Lipizzan/Posavina/Gidran } \\
\text { Noriker }\end{array}$ & $\begin{array}{l}0.000 \\
0.000\end{array}$ & $\begin{array}{c}\text { HOXB3, HOXB1, } \\
\text { HOXB2, HOXB7, } \\
\text { HOXB8, HOXB5, HOXB6 } \\
\text { HOXB3, HOXB1, PCGF2, } \\
\text { HOXB2, HOXB7, } \\
\text { HOXB8, HOXB5, HOXB6 }\end{array}$ & $<=0.001$ \\
\hline $\begin{array}{c}\text { GO:0021570 rhombomere } \mathrm{Li} \\
4 \text { development }\end{array}$ & $\begin{array}{l}\text { Lipizzan/Posavina/Noriker/ } \\
\text { Gidran }\end{array}$ & 0.003 & НОХВ1, НОХВ2 & $0.06-0.99$ \\
\hline $\begin{array}{l}\text { GO:0021612 facial nerve } \\
\text { structural organization }\end{array}$ & $\begin{array}{l}\text { Lipizzan/Posavina/Noriker/ } \\
\text { Gidran }\end{array}$ & 0.011 & НОХВ1, НОХВ2 & $0.18-0.98$ \\
\hline $\begin{array}{l}\text { GO:0048704 embryonic } \\
\text { skeletal system } \\
\text { morphogenesis }\end{array}$ & $\begin{array}{l}\text { Lipizzan/Posavina/Gidran } \\
\text { Noriker }\end{array}$ & $\begin{array}{l}0.000 \\
0.000\end{array}$ & $\begin{array}{c}\text { HOXB3, HOXB1, } \\
\text { HOXB2, HOXB7, } \\
\text { HOXB8, HOXB5, HOXB6 } \\
\text { HOXB3, HOXB1, PCGF2, } \\
\text { HOXB2, HOXB7, } \\
\text { HOXB8, HOXB5, HOXB6 }\end{array}$ & $<0.001$ \\
\hline $\begin{array}{l}\text { GO:0071222 cellular } \\
\text { response to } \\
\text { lipopolysaccharide }\end{array}$ & $\begin{array}{c}\text { Akhal Teke } \\
\text { Purebred Arabian }\end{array}$ & $\begin{array}{l}0.034 \\
0.011\end{array}$ & $\begin{array}{c}\text { IL6, NR1D1, RARA } \\
\text { NR1D1, NFKB1, RARA, } \\
\text { SPON2 }\end{array}$ & 0.99 \\
\hline GO Cellular component & Breeds sharing term & $p$-value & Genes & BH $p$-value \\
\hline GO:0005654 nucleoplasm & Akhal Teke & 0.010 & $\begin{array}{c}\text { COASY, CDC6, } \\
\text { HSD17B1, BBX, ACLY, } \\
\text { BANP, CNP, STAT3, } \\
\text { SMARCE1, ZMIZ2, } \\
\text { DNAJC7, ATP6V0A1, } \\
\text { TOP2A } \\
\text { CWC25, MRPL10, } \\
\text { HOXB7, PSMB3, SNF8, } \\
\text { PNPO, HOXB13, KPNB1, } \\
\text { PIP4K2B }\end{array}$ & $0.36-0.57$ \\
\hline $\begin{array}{l}\text { GO:0005882 intermediate } \\
\text { filament }\end{array}$ & $\begin{array}{l}\text { Shagya Arabian } \\
\text { Purebred Arabian }\end{array}$ & $\begin{array}{l}0.002 \\
0.000\end{array}$ & $\begin{array}{c}\text { KRT26, KRT25, KRT28, } \\
\text { KRT27, KRT24 } \\
\text { KRT26, KRT25, KRT28, } \\
\text { KRT27, KRT12, KRT20, } \\
\text { KRT23, KRT24 }\end{array}$ & $<0.001-0.02$ \\
\hline GO Molecular function & Breeds sharing term & $p$-value & Genes & BH $p$-value \\
\hline $\begin{array}{l}\text { GO:0003700 transcription } \\
\text { factor activity, } \\
\text { sequence-specific DNA } \\
\text { binding }\end{array}$ & $\begin{array}{c}\text { Gidran } \\
\text { Lipizzan/Posavina } \\
\text { Noriker }\end{array}$ & $\begin{array}{l}0.033 \\
0.007 \\
0.012\end{array}$ & $\begin{array}{c}\text { HOXB2, HOXB7, } \\
\text { HOXB8, HOXB6, NFKB1, } \\
\text { CBFA2T3, TCF25, FOXP2 } \\
\text { HOXB2, HOXB7, } \\
\text { HOXB8, HOXB6 } \\
\text { HOXB2, HOXB7, } \\
\text { HOXB8, HOXB6, ZFAT }\end{array}$ & $0.11-0.99$ \\
\hline $\begin{array}{l}\text { GO:0005198 structural } \\
\text { molecule activity }\end{array}$ & $\begin{array}{l}\text { Shagya Arabian } \\
\text { Purebred Arabian }\end{array}$ & 0.000 & $\begin{array}{l}\text { KRT26, KRT25, KRT28, } \\
\text { KRT27, EPB41, KRT24 } \\
\text { KRT26, KRT25, KRT28, } \\
\text { KRT27, KRT12, KRT20, } \\
\text { KRT23, KRT24 }\end{array}$ & $0.02-0.99$ \\
\hline $\begin{array}{l}\text { GO:0015299 solute:proton } \\
\text { antiporter activity }\end{array}$ & $\begin{array}{c}\text { Purebred } \\
\text { Arabian/Gidran }\end{array}$ & 0.044 & SLC9B1, SLC9B2 & 0.99 \\
\hline $\begin{array}{l}\text { GO:0043565 sequence-specifi } \\
\text { DNA binding }\end{array}$ & Lipizzan/Posavina/Noriker & 0.000 & $\begin{array}{c}\text { HOXB1, HOXB2, } \\
\text { HOXB7, HOXB6, } \\
\text { HOXB13, PPARGC1A, } \\
\text { FOXP2 } \\
\text { HOXB1, HOXB2, } \\
\text { HOXB7, HOXB6, } \\
\text { HOXB13 }\end{array}$ & $0.007-0.92$ \\
\hline
\end{tabular}


Two breed specific annotation clusters were significantly enriched after correcting for multiple testing $(p<0.05)$ within the French Trotter (GO:0005178, integrin binding, based upon ICAM1, ICAM4, ICAM5 and ICAM3) and the Purebred Arabian (GO:0005198, structural molecule activity, based upon KRT-complex) (Supplementary File 7).

\section{Discussion}

Due to its huge economic impact and its global genetic introgression into a wide range of contemporary horse breeds, the English Thoroughbred has been in the focus of genomic publications for the last decades [1,42-45]. For a range of Middle European horse breeds, the Arabian horse represented an equivalent source of genetic improvement, which in a historical context preceded the refinement by the Thoroughbred. For nine of the analysed breeds in this study (Purebred Arabian, Shagya Arabian, Akhal Teke, Lipizzan, Bosnian Mountain Horse, Posavina, Haflinger, Noriker, and Exmoor Pony) the absence of introgression of the English Thoroughbred is historically documented. Hence, we only identified few $\mathrm{ROH}$ islands in genomic regions that were targets of positive selection in the English Thoroughbred [1].

ECA3 and ECA11 were common ROH island hotspots in nearly all breeds of our dataset, except for French Trotter and Selle Francais, harboring genes involved in coat color (ECA3: MC1R), size (ECA3: LCORL/NCAPG, ECA11: LASP1), NER pathway (ECA3: UVSSA), embryonic skeletal morphogenesis (ECA11: HOXB-cluster) and coat texture (ECA11: KRT-complex). Recently, Gurgul et al. [7] identified ECA11 as a major selection signature hotspot in six Polish horse breeds with a similar type composition (two draught horse breeds, two autochthonous/primitive breeds, one oriental and one Warmblood horse breed). The authors focused on diversifying selection signatures by grouping the breeds into different major horse type categories (light, primitive and draught type). Based upon this grouping they detected a strong signal between draught and primitive breeds on ECA11 within the LASP1 locus associated with body size [35], a region which overlapped with a $\mathrm{ROH}$ island (23.2-23.4 Mb) detected in the Noriker sample.

Nolte et al. [21] identified selection signatures on ECA11 for the HOXB-cluster in four German sport horse breeds (Hannoveraner, Holsteiner, Oldenburger and Trakehner). The HOXB-cluster was present in $\mathrm{ROH}$ islands of Lipizzan, Noriker, Posavina and Gidran horses, and was significantly highlighted by the GO terms embryonic skeletal morphogenesis and anterior/posterior pattern specification in all four breeds. HOX genes play a fundamental role for morphological diversity in animals and for the control of axial morphology along the anterior-posterior body axis [36]. On the same chromosome an up to $1.3 \mathrm{Mb}$ long $\mathrm{ROH}$ island was detected in the Arabian breeds and the Achal Teke (slightly under the threshold) containing several members of the KRT complex (KRT 12, 20, 23-28), which were also pinpointed by GO analysis revealing the terms hair follicle morphogenesis and intermediate filament. Keratin proteins represent a major part of the protective matrix of the skin, hair and horn in mammals [46], and KRT25 and SP6 were associated with curly coat in Bashkir Curly Horses and Missouri Foxtrotters by Thomer et al. [47]. A variant (KRT25:p.R89H) in the KRT25 gene was found to be responsible for the curly phenotype in North-American and French horses [48]. The keratin driven GO term intermediate filament was also documented in the aforementioned study by Nolte et al. [21].

Coat color, one of the major documented targets of selection during the domestication process $[49,50]$, represents a central breeding objective in five of the investigated breeds (Lipizzan, Haflinger, Gidran, Exmoor Pony and Noriker). We found an up to $2.5 \mathrm{Mb}$ long homozygous region on ECA3 in Gidran, Haflinger and Purebred Arabian horses around the MC1R locus responsible for chestnut coat color [51]. A haplotype around MC1R was previously reported by McCue et al. [4] and Petersen et al. [5]. The investigated breeds with high frequencies of chestnut phenotype harbored two additional islands on ECA3, in which among others the genes NFKB1, SLC39A8, BANK1, UVSSA and MAEA are located. In two linked non-synonymous intronic SNPs of the UVSSA gene oriental breeds exhibited convergent minor allelic and genotype frequencies. Interestingly, the Lipizzan where the majority of the gene pool originates from Spanish Horses [52] clustered to the Oriental group. 
A mutation in the UVSSA gene has been found to be causative for the autosomal recessive disorder UV-sensitive syndrome in humans and together with USP7 it mediates the transcription-coupled nucleotide excision repair [39]. The SLC39A8 gene encodes a transmembrane protein that acts as a transporter of several cations, including zinc. Zinc is essential for various cellular functions and zinc deficiency causes a broad range of disorders in humans and animals, such as growth retardation, immune dysfunctions, diarrhea, and skin diseases [53]. A mutation in BANK1 was associated with the autoimmune disorder systemic lupus erythematous in humans [54]. Finally, the gene NFKB1, a member of the NF-kB transcription factor family, regulates a large number of genes involved in inflammation, cell cycle and cell survival. The NF-kB signaling pathway is important for the maintenance of immune homeostasis in epithelial tissues, especially in the regulation of homeostasis and inflammation in skin [55]. Our study revealed very high frequencies (up to 95\%) of chestnut horses harboring NFKB1, SLC39A8, BANK1 and UVSSA in ROH islands, and indicated evidence that these genes may be involved in the reported higher susceptibility of chestnut horses for skin disorders [56]. Additionally, we identified within the Gidran sample an ROH island containing the STX17 haplotype, responsible for gray coat color [57]. This island was nearly identical in length with the ROH island of Lipizzan horses, containing the genes NR4A3, STX17, ERP44 and INVS [18]. The gray haplotype in non-gray horses was firstly reported by Pielberg et al. [57,58] and predominantly found in Oriental horses. All these findings support a connection between the gray locus and the Oriental horse gene pool.

In Exmoor Ponies we identified a ROH island on ECA22 containing the ASIP gene responsible for bay coat color [38] and one island on ECA1 harboring the genes OCA2 and HERC2. In humans several SNPs in the OCA2 and HERC2 genes were associated with eye, skin, and hair pigmentation [40]. Fernández et al. [59] found evidence that OCA2 has an effect on skin color intensity in red strain of Iberian pigs. OCA2 and HERC2 were suggested as candidate genes for the leopard spotting pattern [60] and for the equine "Tiger-eye" phenotype by Kowalski and Bellone [61] but could not be confirmed [62]. To our knowledge, no investigation on the influence of OCA2/HERC2 on the mealy phenotype, as exhibited by the Exmoor Pony, has been conducted. Mealy coat color in the Exmoor breed was recently proposed to be linked to the EDN3 locus in a study focusing on harness trotting traits [63]. As a homozygous region around EDN3 was also found in non-mealy Hungarian Lipizzan subpopulation [18], we suggest further research including phenotypic data. We did not identify $\mathrm{ROH}$ islands around the KITLG gene on ECA28 which was previously reported to undergo selection in several horse breeds [8,16]. From the various functions of KITLG, also known as mast cell growth factor, which is involved in processes affecting melanogenesis, haematopoiesis and gametogenesis, melanogenesis has been in the focus of scientific research in equine genetics [16,64-66].

As already mentioned, most of our samples were not influenced by the English Thoroughbred gene pool. Nevertheless, the genes STXBP4 and COX11, which were undergoing positive selection in Thoroughbreds [1] and were also listed among other 123 genes exposed to selection during domestication process [8], were present in $\mathrm{ROH}$ islands of the Bosnian Mountain Horse, Exmoor Pony and Noriker. Other Thoroughbred related genomic regions were identified in the Anglo-Arabian Gidran breed. The gene PPARGC1A, a candidate gene for physical performance in Thoroughbreds [1] was located in a $444 \mathrm{~kb}$ long $\mathrm{ROH}$ island of the Gidran. PPARGC1A encodes PGC-1 $\alpha$, which is a transcriptional co-activator that regulates genes involved in energy metabolism and mitochondrial biogenesis through expression of nuclear signaling proteins [67]. The overrepresentation of genes involved in transcription was underlined in four GO terms (transcription factor complex, nucleus, sequence-specific DNA binding, DNA-binding transcription factor activity). Additionally, seven $\mathrm{ROH}$ island on ECA4 were identified within the Gidran sample, three islands directly overlapped with one of the genes CDK6, HDAC9, and FOXP2. Pilegaard et al. [68] reported that endurance exercise induces transient transcriptional activation of the PGC-1 $\alpha$ in human skeletal muscle, and Eivers et al. [69] postulated a PGC-1 $\alpha$ exercise induced role of HDAC9 in the myogenesis of horses.

In general, ECA4 and ECA7 were $\mathrm{ROH}$ island hotspots in the performing and oriental breeds, which shared homozygous segments in six genomic regions and partially overlapped with $\mathrm{ROH}$ 
islands found in Hannoveraner, Holsteiner, Oldenburger and Trakehner [21]. The authors pinpointed selection signatures for IGFBP-1, 3 and 4. IGFBP-1 and IGFBP-3, which were located in ROH islands of the French Trotter, were highlighted by the GO terms IGF I binding (GO:00312994) and IGF II binding (GO:0031995).

For the French Trotter, which genealogically has been influenced by the Standardbred and therefore simultaneously by the Thoroughbred founder gene pool, a closer link to Thoroughbred specific selection signatures was not observed. Due to the specification on differing locomotion patterns (trot and pace), selection favored different genomic regions on a long term. We identified in the French Trotter a $\mathrm{ROH}$ island on ECA23 containing the DMRT3 gene. A mutation in DMRT3 is causative for ambling locomotion pattern and favorable effect on harness racing performance in horses [37]. Single SNPs in DMRT3 were also associated with age-dependent trotting ability by Ricard et al. [70].

ECA7 was a $\mathrm{ROH}$ island hotspot within the French Trotter, which exhibited four $\mathrm{ROH}$ islands between $39.6 \mathrm{Mb}$ and $52.5 \mathrm{Mb}$, comprising together a length of $10.1 \mathrm{Mb}$. Petersen et al. [5] reported extended haplotypes for Standardbred on ECA7. The homozygous region of the French Trotter overlapped at position 39.5-41.1 Mb with islands of Shagya and Purebred Arabians, in which among others the genes NTM and OPCML are located. These genes, associated with intelligence and cognitive functions in humans [71,72], and hypothesized to modulate temperament in horses were highlighted by Gurgul et al. [7] focusing on signals of diversifying selection between light versus draught horses. Additionally, the authors found high linkage disequilibrium (LD) in the chromosomal area between $40.1 \mathrm{Mb}$ and 52.2 $\mathrm{Mb}$ in Arabian and Malopolski horse, which corresponded with the extended $\mathrm{ROH}$ island of the French Trotter at $39.6 \mathrm{Mb}$ and $52.5 \mathrm{Mb}$ [7]. Avila et al. [73] also proposed that NTM might influence temperament of pleasure horses. We identified a further gene on ECA6, which might be involved in behavioral traits. The gene GRINB2, located in the ROH islands of French Trotter and Gidran, is involved in enhanced learning ability in mice [74] and it was associated with career earnings in the Swedish Coldblooded Trotter, and further proposed to affect learnability in horses [75].

Body size and height of withers are important breeding objectives and are well investigated. Makvandi-Nejad et al. [35] associated four loci (LCORL/NCAPG, ZFAT, LASP1 and HGMA2) with body size in horses. Signer-Hasler et al. [41] further identified SNPs in the ZFAT gene, which were associated with height at withers. Selection signatures around NCAPG on ECA3 and LASP1 on ECA11 were identified by Petersen et al. [5] in pony and draught horse breeds and by Gurgul et al. [7] in primitive (Huzul and Konik) and draught horse breeds. Our results were in concordance with these findings and we identified $\mathrm{ROH}$ islands for size associated loci in draught horse breeds (Noriker (LCORL/NCAPG, ZFAT and LASP1) and Posavina (ZFAT)) and Exmoor Pony (LCORL/NCAPG and HMGA2). Interestingly also the Gidran, a multipurpose riding horse, exhibited a $636 \mathrm{~kb}$ long island on ECA 6 containing HMGA2.

Three breeds in our study (Noriker, Bosnian Mountain Horse and Exmoor Pony) can be considered as very old autochthonous breeds, adapted to semi-feral rearing conditions on a long term. The Noriker and the Bosnian Mountain Horse originate from the Alpine/Dinaric region, an environment characterized by high altitude, difficult terrain, cold temperature and deprivation of nutrition, especially in winter. High altitude exposes animals to permanent oxidative stress and results in adaption of the blood, cardiovascular, pulmonary and muscle systems. In all three breeds, we identified a common $\mathrm{ROH}$ island on ECA11 containing the genes STXBP4, COX11, HLF and MMD (additional TMEM100 and PCTP in Exmoor Ponies). All these genes were highlighted in a study investigating adaptation to high altitude in the Andean Horse [76]. Environmental conditions and different performance disciplines can affect similar physiological mechanisms. Three further genes (METTL5, UBR3 and $M Y O 3 B$ ) highlighted in the high-altitude study of Hendrickson [76] were also present in $\mathrm{ROH}$ islands on ECA18 for the breeds French Trotter, Gidran, Selle Francais and Shagya Arabian. Autophagy, a strategy to cope with starvation, is in the focus of human genetic research [77,78]. Within the Bosnian Mountain Horse and the Purebred Arabians, we identified an $\mathrm{ROH}$ island containing the genes $R A L B$ and $I N H B B$. Bodemann et al. [79] described RALB (Ras-like G-protein) as a regulatory 
switch to promote autophagosome biogenesis. We found three $\mathrm{ROH}$ islands in Purebred and Shagya Arabians pinpointing the genes LAPTM4B and IDUA. LAPTM4B (Lysosomal protein transmembrane 4 beta) promotes autophagosome and lysosome fusion [80]. Finally, the gene CALCOCO2, involved in selective autophagy [81], was present in $\mathrm{ROH}$ islands of Posavina, Gidran, Bosnian Mountain Horse, Haflinger and Noriker, whereas for the latter additionally the genes OSBPL, PIP4K2B were highlighted in the GO term autophagosome. The accumulation of genes involved in autophagy in breeds, which are known to be selected for low-input and extensive rearing systems, needs further investigations including phenotypic data.

Within the Exmoor Pony, no autophagy related genes were highlighted. A well-known evolutionary adaption in mammalians, generally known as island or Foster's rule, is the decrease of body size due to limited space and nutrition [82]. Among the investigated horse breeds the Exmoor Pony exhibits the smallest body size at an average height at withers of $120 \mathrm{~cm}$. This characteristic was also pinpointed by the genotype results for size associated loci. Additionally, the $662 \mathrm{~kb}$ long $\mathrm{ROH}$ island on ECA6 in Exmoor Pony at position 81.12-81.80 Mb harboring the genes HMGA2, LLPH, IRAK3 and HELB supports these considerations. Norton et al. [83] identified ancestral haplotypes between ECA6:81.16-81.58 associated with height and baseline insulin values in Welsh ponies and supposed HMGA2 and IRAK3 as candidate genes involved in the equine metabolic syndrome.

Summarizing the results of our study, we found genes located within $\mathrm{ROH}$ islands and shared by more than $50 \%$ of a breed, for coat color in Purebred Arabian, Haflinger, Gidran (MC1R), in Lipizzan and Gidran (STX17) and in Exmoor Pony (ASIP) and additionally for coat quality (KRT-complex) in Purebred Arabian and Shagya Arabian. Size associated loci were pinpointed in draught horses (Noriker (LCORL/NCAPG, ZFAT and LASP1), Posavina (ZFAT)), Exmoor Pony (LCORL/NCAPG and HMGA2) and Gidran (HMGA2). Within Gidran and French Trotter selection for behavioral traits was indicated by GRINB2 and NTM/OPCML. Selection targets for racing performance, exercise and gait pattern was shown for French Trotter (DMRT3, IGFBP-1 and IGFBP-3) and for Gidran (PPARGC1A), whereas conformation breeding was pinpointed by the $H O X B$-cluster in four breeds (Lipizzan, Noriker, Posavina and Gidran). Several genes related to organism response to oxidative stress were embedded in $\mathrm{ROH}$ islands for the autochthonous breeds Bosnian Mountain Horse, Noriker and Exmoor Pony (COX11, STXBP4, HLF and MMD) and in the oriental and performing breeds (SSB, METTL5, UBR3 and $M Y O 3 B$ ). Finally, genes involved in autophagy were underlined for Purebred Arabian, Gidran, Bosnian Mountain Horse and Noriker (CALCOCO2, RALB and LAPTM4B).

\section{Conclusions}

This study highlighted several genes which were located in regions putatively undergoing artificial and/or natural selection. Many of these genes were causative or associated with traits which are part of breeding objectives in the respective breeds. Besides artificial selection, the post-domestication process has not prevented natural influences. Our study revealed several genes involved in adaption to high altitude and genes which may play a role in the adaption to a lack of nutrition in horses. To validate the presented putative areas of selection, we suggest further investigation including phenotype information. According to the methodical point of view, we demonstrated that $\mathrm{ROH}$ island analysis offers the possibility to identify common targets of selection in divergent breeds. Therefore, this approach provides a wider perspective and an enhanced insight into the complexity of biological processes and physiological functions of equines.

Supplementary Materials: The following are available online at http://www.mdpi.com/2073-4425/10/7/491/s1; Suppl. File 1 S1: ROH islands per breed, Suppl. File 2 S2: Illustrations of chromosomes and ROH islands per each breed, Suppl. File 3 S3: ROH distribution on ECA7 in the breeds French Trotter and Selle Francais, Suppl. File 4 S4: Genotype distribution for the MC1R locus in the twelve studied breeds, Suppl. File 5 S5: Genotype and minor/major allele frequencies of the SNP AX-103191894 in intron 7 of the UVSSA gene, Suppl. File 6 S6: Genotype frequencies of SNPs at the loci LCORL/NCAPG, ZFAT and LASP1 for the breeds Bosnian Mountain Horse and Exmoor Pony, Suppl. File 7 S7: Gene Ontology and enrichment analysis. 
Author Contributions: Conceptualization, G.G.-S. and T.D.; methodology, G.G.-S.; M.N. and T.D.; formal analysis, M.N.; G.G.-S. and T.D.; resources, A.R.; M.H.; B.V.; G.L.; M.M.; M.C.; T.D. and G.B.; data curation, M.N.; M.M.; M.C.; writing —original draft preparation, G.G.-S.; writing—review and editing, G.G.-S.; T.D. and M.N.; visualization, G.G.-S.; T.D. and M.N.; project administration, T.D.; funding acquisition, T.D. and G.B.

Funding: This work was financially supported by the Austrian Research Promotion Agency (FFG), Contract number 843464; the Federal Ministry for Sustainability and Tourism (BMNT), Contract number 101332, and Slovenian Research Agency program P4-0053 to M. Cotman. Data collection and genotyping of the Exmoor Pony received funding from the European Union's Seventh Framework Programme managed by REA-Research Executive Agency; http://ec.europa.eu/research/rea (FP7/2007-2013) under grant agreement no. 606142 and The Exmoor Pony Society in UK.

Acknowledgments: We want to thank the Austrian and Slovenian horse breeding associations for supporting data collection. The Exmoor Pony Society in UK is thanked for sampling of horses. Open Access Funding by the University of Veterinary Medicine Vienna.

Conflicts of Interest: Gabriella Lindgren is co-inventor on a granted patent concerning commercial testing of the DMRT3 mutation: A method to predict the pattern of locomotion in horses. PCT EP12 747 875.8. European patent registration date: 2011-05- 05; US patent registration date: 2011-08-03.

Data Availability: The primary data of this study are owned by different research groups. Primary data of the breeds Lipizzan, Noriker, Haflinger, Akhal Teke, Shagya Arabian, Gidran, Bosnian Mountain Horse and Posavina are available from project consortium FFG project number 843464, Veterinary University Vienna, Xenogenetik, five European state stud farms and the Austrian and Slovenian Horse breeders Association, but restrictions apply to the availability of these data, which were used under license for the current study, and so are not publicly available. Data are however available from the authors upon reasonable request and with permission of project consortium, FFG project number 843464, Veterinary University Vienna, Xenogenetik and partners. Genotype data for the Exmoor Pony breed will be provided by contacting authors Lindgren/Velie or for a larger data set via the following reference: Velie, B.D.; Shrestha, M.; François, L.; Schurink, A.; Tesfayonas, Y.G.; Stinckens, A.; Blott, S.; Ducro, B.J.; Mikko, S.; Thomas, R.; Swinburne, J.E.; Sundqvist, M.; Eriksson, S.; Buys, N.; Lindgren, G. Using an inbred horse breed in a high density genome-wide scan for genetic risk factors of insect bite hypersensitivity (IBH). PLoS One. 2016, 11, e0152966.

\section{References}

1. Gu, J.; Orr, N.; Park, S.D.; Katz, L.M.; Sulimova, G.; MacHugh, D.E.; Hill, E.W. A genome scan for positive selection in thoroughbred horses. PLoS ONE 2009, 4, e5767. [CrossRef] [PubMed]

2. Petersen, J.L.; Mickelson, J.R.; Cothran, E.G.; Andersson, L.S.; Axelsson, J.; Bailey, E.; da Câmara Machado, A. Genetic diversity in the modern horse illustrated from genome-wide SNP data. PLoS ONE 2013, 8, e54997. [CrossRef] [PubMed]

3. Schaefer, R.J.; Schubert, M.; Bailey, E.; Bannasch, D.L.; Barrey, E.; Bar-Gal, G.K.; Brem, G.; Brooks, S.A.; Distl, O.; Fries, R. Developing a 670k genotyping array to tag $2 \mathrm{M}$ SNPs across 24 horse breeds. BMC Genom. 2017, 18, 565-583. [CrossRef] [PubMed]

4. McCue, M.E.; Bannasch, D.L.; Petersen, J.L.; Gurr, J.; Bailey, E.; Binns, M.M.; Leeb, T. A high density SNP array for the domestic horse and extant Perissodactyla: Utility for association mapping; genetic diversity; and phylogeny studies. PLoS Genet. 2012, 8, e1002451. [CrossRef] [PubMed]

5. $\quad$ Petersen, J.L.; Mickelson, J.R.; Rendahl, A.K.; Valberg, S.J.; Andersson, L.S.; Axelson, J.; Bailey, E.; Bannesch, D.; Binns, M.M.; Borges, A.S. Genome-wide analysis reveals selection for important traits in domestic horse breeds. PLoS ONE 2013, 9, e10003211. [CrossRef] [PubMed]

6. Zhang, C.; Ni, P.; Ahmad, H.I.; Gemingguli, M.; Baizilaitibei, A.; Gulibaheti, D.; Fang, Y.; Wang, H.; Asif, A.R.; Xiao, C.; et al. Detecting the population structure and scanning for signatures of selection in horses (Equus caballus) from whole-genome sequencing data. Evol. Bioinform. 2018, 14, 1-9. [CrossRef] [PubMed]

7. Gurgul, A.; Jasielczuk, I.; Semik-Gurgul, E.; Pawlina-Tyszko, K.; Stefaniuk-Szmukier, M.; Szmatoła, T.; Polak, G.; Tomczyk-Wrona, I.; Bugno-Poniewierska, M. A genome-wide scan for diversifying selection signatures in selected horse breeds. PLoS ONE 2019, 30, e0210751. [CrossRef]

8. Schubert, M.; Jónsson, H.; Chang, D.; Der Sarkissian, C.; Ermini, L.; Ginolhac, A.; Fumagalli, M. Prehistoric genomes reveal the genetic foundation and cost of horse domestication. Proc. Natl. Acad. Sci. USA 2014, 111, e5661-e5669. [CrossRef]

9. Librado, P.; Gamba, C.; Gaunitz, C.; Der Sarkissian, C.; Pruvost, M.; Albrechtsen, A.; Serres-Armero, A. Ancient genomic changes associated with domestication of the horse. Science 2017, 356, 442-445. [CrossRef] 
10. Lewontin, R.C.; Krakauer, J. Distribution of gene frequency as a test of the theory of the selective neutrality of polymorphisms. Genetics 1973, 74, 175-195.

11. Fariello, M.I.; Boitard, S.; Naya, H.; SanCristobal, M.; Servin, B. Detecting signatures of selection through haplotype differentiation among hierarchically structured populations. Genetics 2013,193, 929-941. [CrossRef] [PubMed]

12. Peripolli, E.; Stafuzza, N.B.; Munari, D.P.; Lima, A.L.F.; Irgang, R.; Machado, M.A.; Panetto, J.C.D.C.; Ventura, R.V.; Baldi, F.; da Silva, M.V.G.B. Assessment of runs of homozygosity islands and estimates of genomic inbreeding in Gyr (Bos indicus) dairy cattle. BMC Genom. 2018, 19. [CrossRef] [PubMed]

13. Peripolli, E.; Metzger, J.; De Lemos, M.V.A.; Stafuzza, N.B.; Kluska, S.; Olivieri, B.F.; Lôbo, R.B. Autozygosity islands and $\mathrm{ROH}$ patterns in Nellore lineages: Evidence of selection for functionally important traits. BMC Genom. 2018, 19. [CrossRef] [PubMed]

14. Bertolini, F.; Cardoso, T.F.; Marras, G.; Nicolazzi, E.L.; Rothschild, M.F.; Amills, M. AdaptMap consortium. Genome-wide patterns of homozygosity provide clues about the population history and adaptation of goats. Genet. Sel. Evol. 2018, 50. [CrossRef] [PubMed]

15. Mastrangelo, S.; Tolone, M.; Sardina, M.T.; Sottile, G.; Sutera, A.M.; Di Gerlando, R.; Portolano, B. Genome-wide scan for runs of homozygosity identifies potential candidate genes associated with local adaptation in Valle del Belice sheep. Genet. Sel. Evol. 2017, 49. [CrossRef] [PubMed]

16. Metzger, J.; Karwath, M.; Tonda, R.; Beltran, S.; Águeda, L.; Gut, M.; Gut, L.G.; Distl, O. Runs of homozygostiy reveal signatures of positive selection for reproduction traits in breed and non-breed horses. BMC Genom. 2015, 16. [CrossRef] [PubMed]

17. Grilz-Seger, G.; Druml, T.; Neuditschko, M.; Mesarič, M.; Cotman, M.; Brem, G. Analysis of ROH patterns in the Noriker horse breed reveal signatures of selection for coat color and body size. Anim. Genet. 2019. [CrossRef]

18. Grilz-Seger, G.; Druml, T.; Neuditschko, M.; Dobretsberger, M.; Horna, M.; Brem, G. High-resolution population structure and runs of homozygosity reveal the genetic architecture of complex traits in the Lipizzan horse. BMC Genom. 2019, 20, 174. [CrossRef]

19. Velie, B.; Solé, M.; Jäderkvist Fegraeus, K.; Rosengren, M.K.; Røed, K.H.; Ihler, C.F.; Strand, E.; Lindgren, G. Genomic measures of inbreeding in the Norwegian-Swedish Coldblooded Trotter and their associations with known QTL for reproduction and health traits. Genet. Sel. Evol. 2019, 51, 22. [CrossRef]

20. Grilz-Seger, G.; Mesarič, M.; Cotman, M.; Neuditschko, M.; Druml, T.; Brem, G. Runs of homozygosity and population history of three horse breeds with small population size. J. Equine Vet. Sci. 2018, 71, 27-34. [CrossRef]

21. Nolte, W.; Thaller, G.; Khuen, C. Selection signatures in four German warmblood horse breeds: Tracing breeding history in the modern sport horse. PLoS ONE 2019, 14, e0215913. [CrossRef] [PubMed]

22. Stud-Book Selle Français. Available online: http://en.sellefrancais.fr/la-race-selle-francais-82-rubrique.html (accessed on 17 June 2019).

23. Equipedia Ifce. Available online: https://equipedia.ifce.fr/elevage-et-entretien/race-et-robe/races-dequideset-stud-book/trotteur-francais.html (accessed on 17 June 2019).

24. Lipizzan International Federation. Available online: http://www.lipizzan-online.com/main.asp?kat1=64\& kat2=543\&kat3=\&vid=1 (accessed on 17 June 2019).

25. Zentrale Arbeitsgemeinschaft Österreichischer Pferdezüchter. Available online: https://www.pferdezuchtaustria.at/main.asp?kat1=2119\&kat2=2817\&kat3=728 (accessed on 17 June 2019).

26. Zentrale Arbeitsgemeinschaft Österreichischer Pferdezüchter. Available online: https://www.pferdezuchtaustria.at/main.asp?kat1=2119\&kat2=2816\&kat3=661 (accessed on 17 June 2019).

27. Mesaric, M. Posavina Zucht in Slowenien. In Das Posavina Pferd; Grilz-Seger, G., Druml, T., Eds.; Vehling Verlag: Graz, Austria, 2018; pp. 57-71.

28. Mihok, S. A Gidran lo Monografiaja; Debrecen, Hungary, 2006.

29. ISG-Shagya-Araber. Available online: http://isg-shagya-araber.de/index.php?entstehungsgeschichte-der-isg-2 (accessed on 17 June 2019).

30. Mesaric, M.; Dolinsek, A.; Dovc, P. Bosnian Mountain Horse; PLANIDO-A.\&A. Dolinsek, and the International Association of Bosnian Mountain Horse Breeders: Ljubljana, Slovenia, 2015. 
31. Wade, C.M.; Giulotto, E.; Sigurdsson, S.; Zoli, M.; Gnerre, S.; Imsland, F.; Blöcker, H. Genome sequence, comparative analysis, and population genetics of the domestic horse. Science 2009, 326, 865-867. [CrossRef] [PubMed]

32. Purcell, S.; Neale, B.; Todd-Brown, K.; Thomas, L.; Ferreira, M.A.; Bender, D.; Maller, J.; Sklar, P.; de Bakker, P.I.; Daly, M.J.; et al. PLINK: A tool set for whole genome association and population-based linkage analyses. Am. J. Hum. Genet. 2007, 81, 559-575. [CrossRef] [PubMed]

33. SAS Institute. SAS Version 9.1; SAS Institute: Cary, NC, USA, 2009.

34. Huang, D.W.; Sherman, B.T.; Lempicki, R.A. Systematic and integrative analysis of large gene lists using DAVID Bioinformatics Resources. Nat. Prot. 2009, 4, 44-57. [CrossRef] [PubMed]

35. Makvandi-Nejad, S.; Hoffman, G.E.; Allen, J.J.; Chu, E.; Gu, E.; Chandler, A.M.; Loredo, A.I.; Bellone, R.R.; Mezey, J.G.; Brooks, S.A.; et al. Four loci explain 83\% of size variation in the horse. PLoS ONE 2012, 7, e39929. [CrossRef] [PubMed]

36. Pearson, J.C.; Lemons, D.; McGinnis, W. Modulating Hox gene functions during animal body patterning. Nat. Rev. Genet. 2005, 6, 893-904. [CrossRef] [PubMed]

37. Andersson, L.S.; Larhammar, M.; Memic, F.; Wootz, H.; Schwochow, D.; Rubin, C.J. Mutations in DMRT3 affect locomotion in horses and spinal circuit function in mice. Nature 2012, 488, 642-646. [CrossRef] [PubMed]

38. Rieder, S.; Taourit, S.; Mariat, D.; Langlois, B.; Guerin, G. Mutation in the agouti (ASIP); the extension (MC1R); and the brown (TYRP1) loci and their association to coat color phenotypes in horses (Equus caballus). Mamm. Gen. 2001, 12, 450-455. [CrossRef] [PubMed]

39. Higa, M.; Zhang, X.; Tanaka, K.; Saijo, M. Stabilization of Ultraviolet (UV)-stimulated Scaffold Protein A by interaction with Ubiquitin-specific Peptidase 7 is essential for Transcription-coupled Nucleotide Excision Repair. J. Biol. Chem. 2016, 291, 13771-13779. [CrossRef]

40. Donnelly, M.P.; Paschou, P.; Grigorenko, E.; Gurwitz, D.; Barta, C.; Lu, R.B.; Li, H. A global view of the OCA2-HERC2 region and pigmentation. Hum. Genet. 2012, 131, 683-696. [CrossRef]

41. Signer-Hasler, H.; Flury, C.; Haase, B.; Burger, D.; Simianer, H.; Leeb, T.; Rieder, S. A genome-wide association study reveals loci influencing height and other conformation traits in horses. PLoS ONE 2012, 7, e37282. [CrossRef] [PubMed]

42. Cunningham, P. The Genetics of Thoroughbred Horses. Sci. Am. 1991, 264, 92-99. [CrossRef]

43. Bower, M.A.; McGivney, B.A.; Campana, M.G.; Gu, J.; Andersson, L.S.; Barrett, E.; Bradley, D.G. The genetic origin and history of speed in the Thoroughbred racehorse. Nature 2012, 3, 643. [CrossRef]

44. Binns, M.M.; Boehler, D.A.; Bailey, E.; Lear, T.L.; Cardwell, J.M.; Lambert, D.H. Inbreeding in the Thoroughbred horse. Anim. Genet. 2012, 43, 340-342. [CrossRef] [PubMed]

45. Hill, E.W.; Gu, J.; McGivney, B.A.; MacHugh, D.E. Targets of selection in the Thoroughbred genome contain exercise-relevant gene SNPs associated with elite racecourse performance. Anim. Genet. 2010, 41, 56-63. [CrossRef]

46. Tomlinson, D.J.; Mulling, C.H.; Fakler, T.M. Formation of keratins in the bovine claw: Roles of hormones, minerals, and vitamins in functional claw integrity. J. Dairy Sci. 2004, 87, 797-809. [CrossRef]

47. Thomer, A.; Gottschalk, M.; Christmann, A.; Naccache, F.; Jung, K.; Hewicker-Trautwein, M.; Distl, O.; Metzger, J. An epistatic effect of KRT25 on SP6 is involved in curly coat in horses. Sci. Rep. 2018. [CrossRef]

48. Morgenthaler, C.; Diribarne, M.; Capitan, A.; Legendre, R.; Saintilan, R.; Gilles, M.; Esquerré, D.; Juras, J.; Khanshour, A.; Schibler, L.; et al. A missense variant in the coil1A domain of the keratin 25 gene is associated with the dominant curly hair coat trait (Crd) in horse. Genet. Sel. Evol. 2017, 49. [CrossRef]

49. Ludwig, A.; Pruvost, M.; Reissmann, M.; Benecke, N.; Brockmann, G.A.; Castaños, P.; Slatkin, M. Coat color variation at the beginning of horse domestication. Science 2009, 324. [CrossRef]

50. Wutke, S.; Benecke, N.; Sandoval-Castellanos, E.; Döhle, H.J.; Friederich, S.; Gonzalez, J.; Morales-Muniz, A. Spotted phenotypes in horses lost attractiveness in the Middle Ages. Sci. Rep. 2016, 6. [CrossRef]

51. Marklund, L.; Moller, M.J.; Sandberg, K.; Andersson, L. A missense mutation in the gene for melanocyte-stimulating hormone receptor (MC1R) is associated with the chestnut coat color in horses. Mamm. Gen. 1996, 7, 895-899. [CrossRef]

52. Zechner, P.; Sölkner, J.; Bodo, I.; Druml, T.; Baumung, R.; Achmann, R.; Marti, E.; Habe, F.; Brem, G. Analysis of diversity and population structure in the Lipizzan horse breed based on pedigree information. Livest. Prod. Sci. 2002, 77, 137-146. [CrossRef] 
53. Takagishi, T.; Hara, T.; Fukada, T. Recent advances in the role of SLC39A/ZIP zinc transporters in vivo. Int. J. Mol. Sci. 2017, 18, 2708. [CrossRef] [PubMed]

54. Kozyrev, S.V.; Abelson, A.K.; Wojcik, J.; Zaghlool, A.; Linga, R. Functional variants in the B-cell gene BANK1 are associated with systemic lupus erythematosus. Nat. Genet. 2008, 40, 211-216. [CrossRef] [PubMed]

55. Wullaert, A.; Bonnet, M.C.; Pasparakis, M. NF-кB in the regulation of epithelial homeostasis and inflammation. Cell Res. 2011, 21, 146-158. [CrossRef]

56. Bellone, R.R.; Liu, J.; Petersen, J.L.; Mack, M.; Singer-Berk, M.; Drögemüller, C.; Malvick, J.; Wallner, B.; Brem, G.; Penedo, M.C.; et al. A missense mutation in damage-specific DNA binding protein 2 is a genetic risk factor for limbal squamous cell carcinoma in horses. Int. J. Cancer 2017, 141, 342-353. [CrossRef]

57. Pielberg, R.G.; Golovko, A.; Sundström, E.; Curik, I.; Lennartsson, J. A cis-acting regulatory mutation causes premature hair graying and susceptibility to melanoma in the horse. Nat. Genet. 2008, 40, 1004-1009. [CrossRef]

58. Pielberg, R.G.; Mikko, S.; Sandberg, K.; Andersson, L. Comparative linkage mapping of the Gray coat colour gene in horses. Anim. Genet. 2005, 36, 390-395. [CrossRef]

59. Fernández, A.; Silió, L.; Rodríguez, C.; Óvilo, C. Characterization of OCA2 cDNA in different porcine breeds and analysis of its potential effect on skin pigmentation in a red Iberian strain. Anim. Genet. 2006, 37, 166-170. [CrossRef]

60. Bellone, R.; Lear, T.; Adelson, D.L.; Bailey, E. Comparative mapping of oculocutaneous albinism type II (OCA2); transient receptor potential cation channel; subfamily M member 1 (TRPM1) and two equine microsatellites; ASB08 and 1CA43; among four equid species by fluorescence in situ hybridization. Cytogenet. Genome Res. 2006, 114, 93. [CrossRef]

61. Kowalski, E.J.A.; Bellone, R. Investigation of HERC2 and OCA2 SNP for iris color variation in Puerto Rican Paso Fino horses. J. Equine Vet. Sci. 2011, 31, 319. [CrossRef]

62. Mack, M.; Kowalski, E.; Grahn, R.; Bras, D.; Cecilia, M.; Penedo, T.; Bellone, R. Two variants in SLC24A5 are associated with "Tiger-Eye" iris pigmentation in Puerto Rican Paso Fino horses. G3 2017, 7, 2799-2806. [CrossRef] [PubMed]

63. Jäderkvist Fegraeus, K.; Velie, B.; Axelsson, J.; Ang, R.; Hamilton, N.A.; Andersson, L.; Meadows, J.R.S.; Lindgren, $\mathrm{G}$. A potential regulatory region near the EDN3 gene may control both harness racing performance and coat color variation in horses. Physiol. Rep. 2018, 6, e13700. [CrossRef] [PubMed]

64. Brooks, S.; Bailey, E. Exon skipping in the KIT gene causes a Sabino spotting pattern in Horses. Mamm. Gen. 2005, 16, 893-902. [CrossRef] [PubMed]

65. Haase, B.; Rieder, S.; Tozaki, T.; Hasegawa, T.; Penedo, M.; Hasegawa, T.; Penedo, M.C.T.; Jude, R.; Leeb, T. Five novel KIT mutations in horses with white coat colour phenotypes. Anim. Gen. 2011, 42, 337-339. [CrossRef] [PubMed]

66. Hauswirth, R.; Jude, R.; Haase, B.; Bellone, R.R.; Archer, S.; Holl, H.; Leeb, T. Novel variants in the KIT and PAX3 genes in horses with white-spotted coat colour phenotypes. Anim. Gen. 2013, 4, 763-765. [CrossRef] [PubMed]

67. Dominy, J.E.; Puigserver, P. Mitochondrial biogenesis through activation of nuclear signaling proteins cold spring harb. Perspect. Biol. 2013, 5, a015008.

68. Pilegaard, H.; Saltin, B.; Neufer, P.D. Exercise induces transient transcriptional activation of the PGC-1 $\alpha$ gene in human skeletal muscle. J. Physiol. 2003, 546, 851-858. [CrossRef]

69. Eivers, S.S.; McGivney, B.A.; Gu, J.; MacHugh, D.E.; Katz, L.M.; Hill, E.M. PGC-1 $\alpha$ encoded by the PPARGC1A gene regulates oxidative energy metabolism in equine skeletal muscle during exercise. Anim. Genet. 2012, 43, 153-162. [CrossRef]

70. Ricard, A. Does heterozygosity at the DMRT3 gene make French trotters better racers? Gen. Sel. Evol. 2015, 47, 10. [CrossRef]

71. Liu, F.; Arias-Vásquez, A.; Sleegers, K.; Aulchenko, Y.S.; Kayser, M.; Sanchez-Juan, P.; Heutink, P. A genome wide screen for late-onset Alzheimer disease in a genetically isolated Dutch population. Am. J. Hum. Genet. 2007, 81, 17-31. [CrossRef] [PubMed]

72. Pan, Y.; Wang, K.S.; Aragam, N. NTM and NR3C2 polymorphisms influencing intelligence: Family-based association studies. Prog. Neuro Psychopharmacol. Biol. Psychiatry 2011, 35, 154-160. [CrossRef] [PubMed] 
73. Avila, F.; Mickelson, J.M.; Schaefer, R.J.; McCue, M. Genome-wide signatures of selection reveal genes associated with performance in American Quarter Horse subpopulations. Front. Genet. 2018, 9, 249. [CrossRef] [PubMed]

74. Tang, Y.P.; Shimizu, E.; Dube, G.R.; Rampon, C.; Kerchner, G.A.; Min, Z.; Liu, G.; Tsien, J.Z. Genetic enhancement of learning and memory in mice. Nature 1999, 401, 63-69. [CrossRef] [PubMed]

75. Velie, B.D.; Fegraeus, K.J.; Solé, M.; Rosengren, M.K.; Røed, K.H.; Ihler, C.F.; Strand, E.; Lindgren, G. A genome-wide association study for harness racing success in the Norwegian-Swedish coldblooded trotter reveals genes for learning and energy metabolism. BMC Genet. 2018, 29, 80. [CrossRef] [PubMed]

76. Hendrickson, S.L. A genome wide study of genetic adaptation to high altitude in feral Andean Horses of the páramo. BMC Evol. Biol. 2013, 13. [CrossRef] [PubMed]

77. Eskelinen, E.L.; Saftig, P. Autophagy: A lysosomal degradation pathway with a central role in health and disease. Biochimica et Biophysica Acta (BBA). Mol. Cell Res. 2009, 17937, 664-673.

78. Xu, T.; Nicolson, S.; Denton, D.; Kumar, S. Distinct requirements of Autophagy-related genes in programmed cell death. Cell Death Differ. 2015, 22, 1792-1802. [CrossRef] [PubMed]

79. Bodemann, B.O.; Orvedahl, A.; Cheng, T.; Ram, R.R.; Ou, Y.; Formstecher, E.; Maiti, M.; Hazelett, C.C.; Wauson, E.M.; Balakireva, M.; et al. RalB and the exocyst mediate the cellular starvation response by direct activation of autophagosome assembly. Cell 2011, 144, 253-267. [CrossRef]

80. Mrschtik, M.; Ryan, K.M. Lysosomal proteins in cell death and autophagy. FEBS J. 2015, 282, $1858-1870$. [CrossRef]

81. Stolz, A.; Ernst, A.; Dikic, I. Cargo recognition and trafficking in selective autophagy. Nat. Cell Biol. 2014, 16, 495-501. [CrossRef] [PubMed]

82. Meiri, S.; Dayan, T.; Simberloff, D. The generality of the island rule re-examined. J. Biogeogr. 2006, 33, 1571-1577. [CrossRef]

83. Norton, E.M.; Avila, F.; Schultz, N.E.; Mickelson, J.R.; Geor, R.J.; McCue, M.E. Evaluation of an HMGA2 variant for pleiotropic effects on height and metabolic traits in ponies. J. Vet. Intern. Med. 2019. [CrossRef] [PubMed]

(C) 2019 by the authors. Licensee MDPI, Basel, Switzerland. This article is an open access article distributed under the terms and conditions of the Creative Commons Attribution (CC BY) license (http://creativecommons.org/licenses/by/4.0/). 